\title{
Centromere Identity, Function, and Epigenetic Propagation across Cell Divisions
}

\author{
B.E. Black, ${ }^{1}$ L.E.T. Jansen, ${ }^{2}$ D.R. Foltz,${ }^{3}$ AND D.W. Cleveland ${ }^{4}$ \\ ${ }^{1}$ Department of Biochemistry and Biophysics, University of Pennsylvania School of Medicine, Philadelphia, \\ Pennsylvania 19104-6059; ${ }^{2}$ Instituto Gulbenkian de Ciência, 2780-156 Oeiras, Portugal; ${ }^{3}$ Department \\ of Biochemistry and Molecular Genetics, University of Virginia, Charlottesville, Virginia 22908; \\ ${ }^{4}$ Ludwig Institute for Cancer Research and Department of Cellular and Molecular Medicine, \\ University of California at San Diego, La Jolla, California 92093 \\ Correspondence: blackbe@mail.med.upenn.edu and dcleveland@ucsd.edu
}

\begin{abstract}
The key to understanding centromere identity is likely to lie in the chromatin containing the histone H3 variant CENP-A. CENP-A is the prime candidate to carry the epigenetic information that specifies the chromosomal location of the centromere in nearly all eukaryotic species, raising questions fundamental to understanding chromosome inheritance: How is the epigenetic centromere mark propagated? What physical properties of CENP-A-containing complexes are important for epigenetically marking centromeres? What are the molecules that recognize centromeric chromatin and serve as the foundation for the mitotic kinetochore? We discuss recent advances from our research groups that have yielded substantial insight into these questions and present our current understanding of the centromere. Future work promises an understanding of the molecular processes that confer fidelity to genome transmission at cell division.
\end{abstract}

Chromosomes, the functional unit of inheritance, must segregate with high fidelity every time a cell divides, and both prokaryotes and eukaryotes have evolved elaborate mechanisms to achieve accurate chromosome delivery (Hayes and Barilla 2006; Santaguida and Musacchio 2009). For eukaryotes, a common mechanism in mitosis is used, in which sister chromatids are physically attached to each other and bidirectionally oriented toward poles of the microtubule-based spindle that physically move complete sets of chromosomes to each daughter cell. This bidirectionally orientated attachment is mediated by a proteinaceous structure, the kinetochore, that forms during mitosis at the microtubule/chromosome interface. The site of kinetochore formation is defined by a region of the chromosome, the centromere. Without functional centromeres, chromosomes are mis-segregated at cell division, leading to aneuploidy in the daughter cells.

In budding yeast, classical experiments defined the centromere as a small ( $\sim 125 \mathrm{bp})$ sequence-specified region of DNA (Clarke and Carbon 1980; Fitzgerald-Hayes et al. 1982). This region is composed of three conserved elements (CDEI, II, and III) and recruits sequence-specific centromeric DNA-binding proteins (such as members of the well-studied CBF3 complex, which is recruited to CDEIII) (Lechner and Carbon 1991). This simple and elegant system for marking centromeres is not conserved, however, in other eukaryotes, except in a subset of related yeasts. For most eukaryotes, the centromere is much larger and is not defined by a particular DNA sequence. For both simple and more complex centromeres, there is a "core" centromeric chromatin at the foundation of the kinetochore, as well as a surrounding specialized chromatin domain (this is defined by highly phased nucleosomes in budding yeast and is a distinct "heterochromatin" domain in flies, mammals, etc.) that is required for sister-chromatid cohesion. Both of these regions of the centromere are essential for successful chromosome transmission at cell division.

\section{EVIDENCE FOR AN EPIGENETIC MECHANISM FOR CENTROMERE IDENTITY}

The centromere is typically located within a region of repetitive satellite DNA in diverse plant and animal phyla (Henikoff et al. 2001; Jiang et al. 2003). In humans, the predominant centromeric satellite, $\alpha$-type I, consists of repeats of 171-bp monomers that extend for several megabases at most centromeres (Fig. 1A) (Manuelidis and Wu 1978; Willard 1985; Willard and Waye 1987). Despite the strong correlation between centromere location and the presence of these satellites, chromosomal rearrangements in humans have revealed instances in which a centromere has been silenced (in the case of rearrangements that would have produced a dicentric chromosome if one of the two centromeres had not been inactivated) (Earnshaw and Migeon 1985; Sullivan and Schwartz 1995) or generated de novo at a chromosome arm locus lacking detectable $\alpha$-satellite DNA (such new centromeres are referred to as "neocentromeres") (Depinet et al. 1997; du Sart et al. 1997; Warburton et al. 1997; Choo 2001). Two human cases have described instances in which a centromere relocated within an intact chromosome 3 or 4, respectively, from the original location to a new location on the chromosome arm (Amor et al. 2004; Ventura et al. 2004). A remarkable finding was that this new location persists in multiple family members for at least two generations (Fig. 1B) (Amor et al. 2004). The ability to permanently silence an existing centromere with no rearrangement or deletion of centromeric repeat DNA sequences, create a 
A
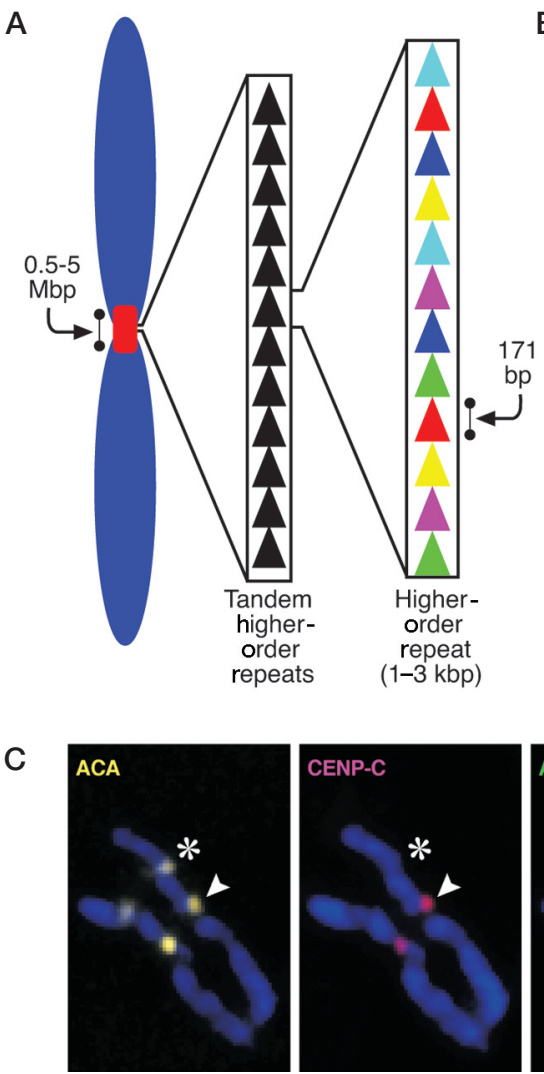

B
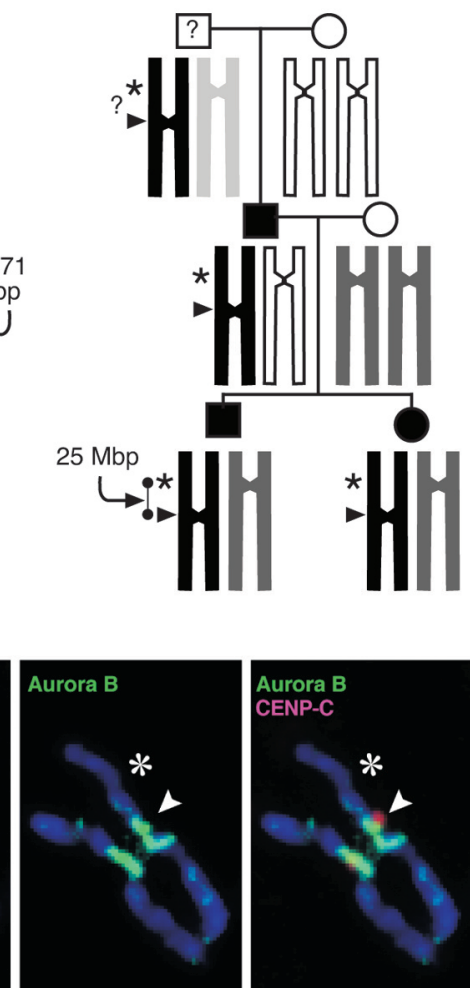

Figure 1. Epigenetic centromere specification. (A) DNA at normal human centromeres is repetitive with a monomer length of $\sim 171$ bp multimerized for megabase stretches. Although this general theme in centromere organization is seen in most eukaryotes, centromeric DNA sequences are among some of the most rapidly evolving sequences in the genome. $(B)$ Stable inheritance of a human neocentromere after centromere relocation along an intact human chromosome 4 (data adapted from Amor et al. 2004). The family pedigree shows the generational inheritance of a neocentromere-containing variant chromosome 4 ("PD-NC4"; black bar). The chromosomal allele containing the neocentromere was inherited from the paternal grandfather of the brother and sister who initially were found to carry PD-NC4. The neocentromere is carried by their father, but the grandfather was not available for study. $(C)$ Relocation of both centromere-specifying chromatin and inner centromere components to the PD-NC4 neocentromere (data adapted from Bassett et al. 2010). Anti-centromere antisera (ACA) recognize both CENP-A at the neocentromere (arrowhead) and CENP-B at the silenced centromere at the original location (asterisk). Kinetochore-forming components, represented by the CENP-A-binding protein CENP$\mathrm{C}$, vacate the original site and relocate to the neocentromere. Inner centromere components, represented by the Aurora B kinase, also vacate the original site and relocate to chromosome arm positions proximal to the neocentromere.

neocentromere at a noncentromeric region of the chromosome that lacks $\alpha$-satellite DNA, or both (Fig. 1B,C), provides substantial support for the notion that human centromeres are not defined by a particular DNA sequence. Such evidence strongly argues that centromere identity is primarily or exclusively specified epigenetically.

In evolutionary terms, the movement of centromere location has emerged as an attractive candidate to participate in the mechanism of speciation (Ventura et al. 2001; Amor et al. 2004). Although speciation events in mammals maintain a high degree of synteny at most sites, centromere location can vary greatly between even closely related species (Carbone et al. 2006). Centromere "repositioning" is correlated to the high evolutionary rate of chromosomal breakpoints that are preferentially found in or near centromeres (Murphy et al. 2005). Interestingly, whereas satellite DNA is typically found at mammalian centromeres, the sequence of the repeat unit is not well conserved (Henikoff et al. 2001).

\section{A CENTROMERE-SPECIFIC H3 VARIANT THAT MARKS CENTROMERES}

The most attractive candidate for an epigenetic mark that specifies the centromere is the histone $\mathrm{H} 3$ variant CENP-A (Earnshaw and Rothfield 1985; Palmer and Margolis 1985; Sullivan et al. 1994). Together with canonical histones $\mathrm{H} 2 \mathrm{~A}, \mathrm{H} 2 \mathrm{~B}$, and $\mathrm{H} 4$, it forms nucleosomes at active centromeres, and CENP-A relatives have an essential role at centromeres in diverse eukaryotic species (Stoler et al. 1995; Buchwitz et al. 1999; Howman et al. 2000; Takahashi et al. 2000; Regnier et al. 2005). CENP-A is found at all active centromeres in a manner that appears to be independent of DNA sequence, including human neocentromeres lacking detectable $\alpha$-satellites (Fig. 1) (Warburton et al. 1997; Amor et al. 2004). Conversely, despite the retention of $\alpha \mathrm{I}$-satellite arrays, CENP-A is absent when centromeres are silenced (Warburton et al. 1997; Amor et al. 2004; Han et al. 2006). To distinguish the cen- 
tromere from chromatin found at all other chromosome locations, CENP-A must somehow physically distinguish the nucleosomes into which it assembles. Contributions to physically marking the centromere could potentially come from its amino-terminal "tail" that lacks conservation among CENP-A orthologs but is uniformly lacking in any sequence identity with conventional histone H3. Alternatively, physical divergence could come from its histone-fold domain, which is relatively conserved among CENP-A orthologs but diverges by 30\%-45\% from H3. Despite this divergence within the histone-fold domain, CENP-A spontaneously forms a heterotetramer following coexpression with its partner histone H4 (Black et al. 2004). Although identical in stoichiometry to the subnucleosomal (H3:H4) ${ }_{2}$ heterotetramer, (CENP-A:H4) ${ }_{2}$ is dynamically and structurally divergent from its conventional counterpart. The first evidence of such divergence - coming from mass spectrometry-based hydrogen/deuterium exchange experiments that dynamically measure the conformational flexibility of the polypeptide backbone - was the finding that the predicted interface between CENP-A and $\mathrm{H} 4$ is $>10$-fold more rigid than the corresponding portion of the (H3:H4), heterotetramer (Black et al. 2004).

The portion of CENP-A, its $\alpha 2$-helix, that contacts histone $\mathrm{H} 4$ and generates the rigid interface is of high interest because it, along with the preceding loop (L1), is the only region of CENP-A where mutation results in defective centromeric targeting (Shelby et al. 1997). Indeed, a chimeric histone $\mathrm{H} 3$ carrying 22 amino acid substitutions from CENP-A in the L1 and $\alpha 2$-helix (Fig. 2A), H3 ${ }^{\text {CATD }}$ (CENP-A targeting domain), targets efficiently to centromeres (Fig. 2B) (Black et al. 2004). Importantly, the chimeric $\mathrm{H} 3^{\text {CATD }}$ forms a tetramer with $\mathrm{H} 4$ that has a nearly identical hydrogen/deuterium exchange profile as bona fide (CENP-A:H4) ${ }_{2}$ heterotetramers (Fig. 2C), and restricted flexibility relative to canonical nucleosomes is maintained after assembly of CENP-A into nucleosomes (Black et al. 2007a). After arriving at centromeres, the H3 ${ }^{\text {CATD }}$ chimera can substitute for CENP-A protein in centromere-specifying nucleosomes, rescuing lethality in cell culture following siRNA-mediated depletion of endogenous CENP-A (Black et al. 2007b).

The molecular nature of (CENP-A:H4) was revealed in atomic detail with high-resolution $(2.1-2.5 \AA)$ crystal structures and lower-resolution solution studies (smallangle X-ray scattering [SAXS]) (Fig. 3) (Sekulic et al. 2010). The structural basis for the rigidified interface with H4 resides in hydrophobic "stitches" between CENP-Aspecific side chains and $\mathrm{H} 4$ that restrict locally polypeptide backbone flexibility (Fig. 3A). In addition, the hydrogen bonding between L1 of CENP-A and L2 of H4 generates a bulge of the opposite charge as is found on conventional (H3:H4), heterotetramers (Fig. 3A,B) (Sekulic et al. 2010) at a location that remains exposed even after assembly into conventional nucleosomes (Luger et al. 1997). Most strikingly, the crystal and SAXS studies revealed a compaction of the entire tetramer by $\sim 10 \AA$ that corresponds to a rotation at the CENP-A/CENP-A interface (Fig. 3A,C)
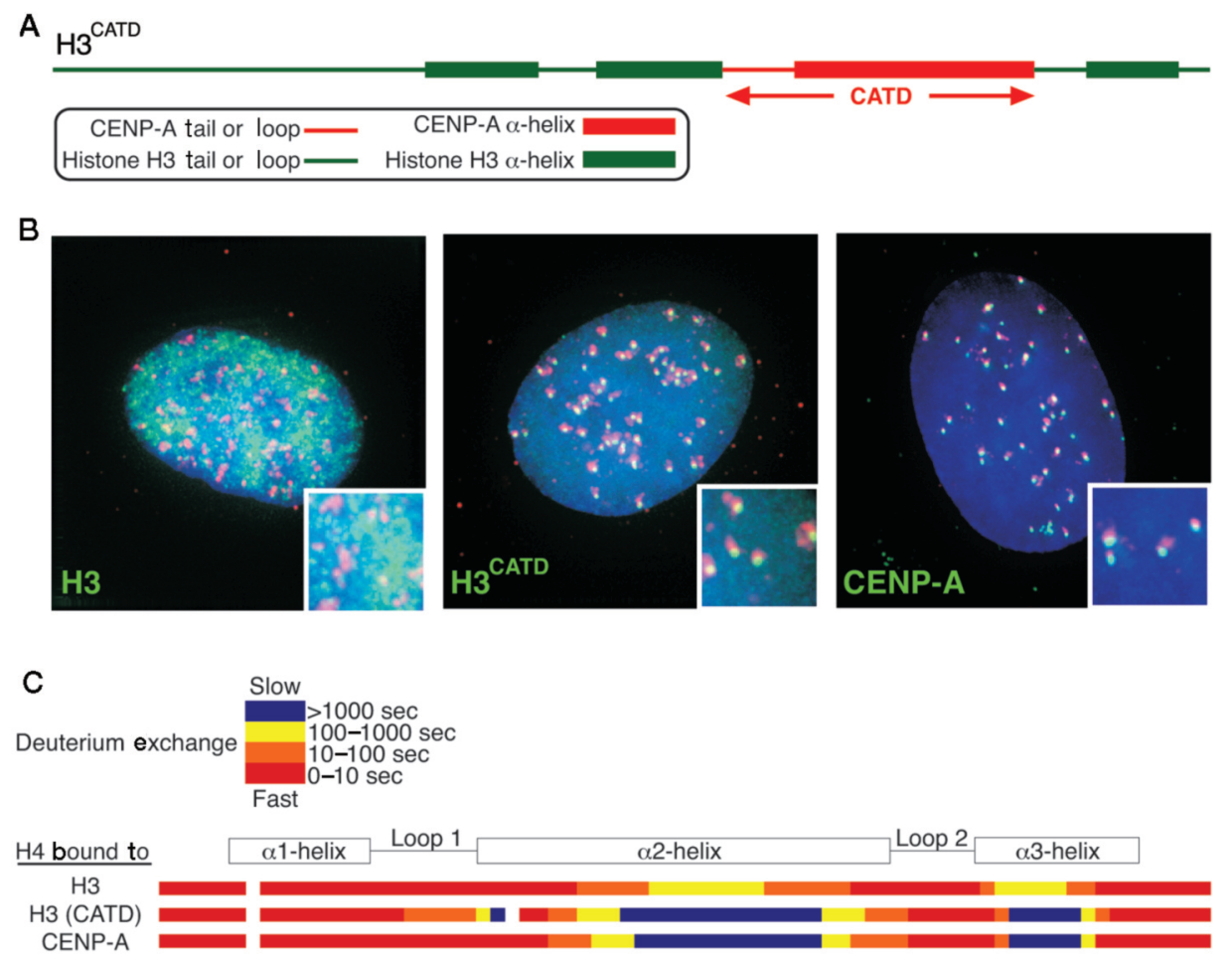

Figure 2. Initial evidence linking the targeting of CENP-A to centromeres with physical divergence from conventional histone $\mathrm{H} 3$ (data adapted from Black et al. 2004). (A) Diagram of a histone H3 chimera containing the CENP-A targeting domain (CATD). (B) Centromere targeting of $\mathrm{H}^{\mathrm{CATD}}$. (C) Hydrogen/deuterium exchange profile of histone H4 bound to conventional H3, the H3 ${ }^{\text {CATD }}$ chimera, and CENP-A. The nearly identically localized blue regions on histone H4 within (CENP-A:H4) ${ }_{2}$ and (H3 ${ }^{\text {CATD }}$ :H4) $_{2}$ heterotetramers are $>10$-fold slower to exchange amide protons with deuterons in heavy water than from any portion within conventional $(\mathrm{H} 3: \mathrm{H} 4)_{2}$, indicating substantial rigidity imparted by the CATD. 


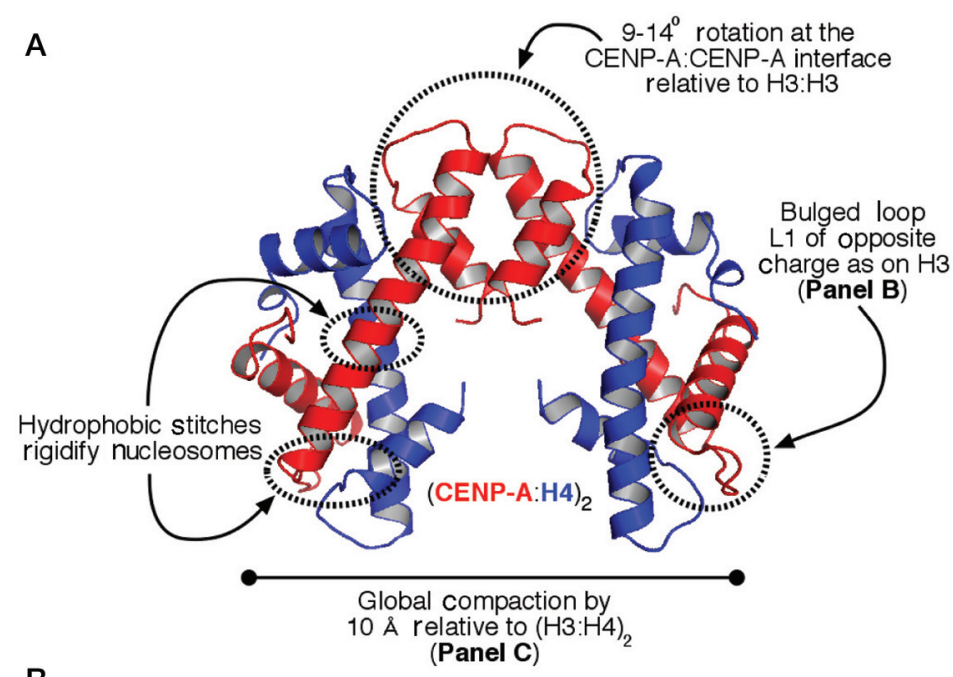

B (Panel C)
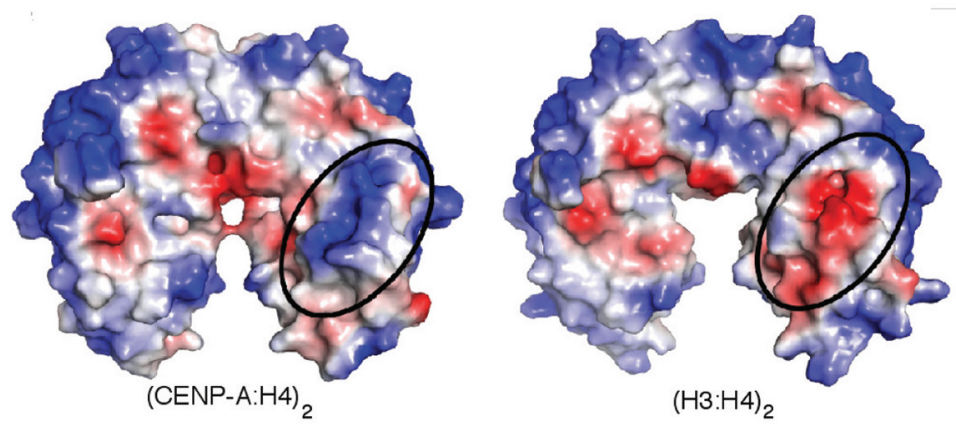

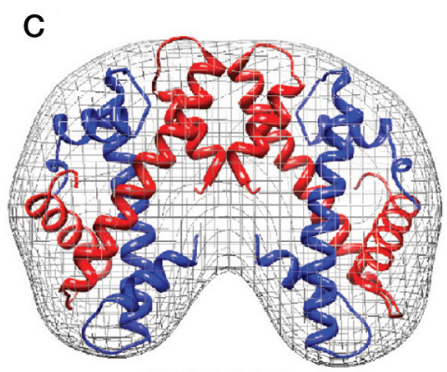

(CENP-A:H4) 2

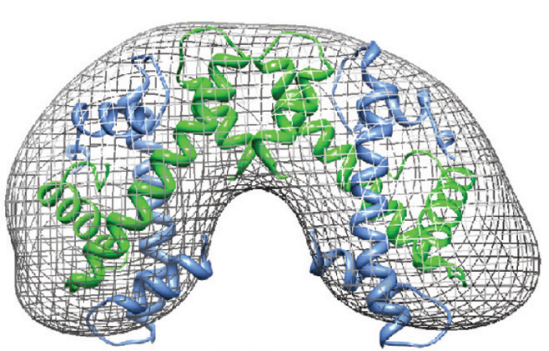

$(\mathrm{H} 3: \mathrm{H} 4)_{2}$

Figure 3. (CENP-A/H4), heterotetramers structurally deviate from their conventional counterparts. $(A)$ Crystal structure of the (CENPA:H4) ${ }_{2}$ heterotetramer (PDB ID 3NQJ) (data adapted from Sekulic et al. 2010) highlighting features that distinguish it from conventional $(\mathrm{H} 3: \mathrm{H} 4)_{2}$. (B) Surface alterations encoded by the CATD of CENP-A include a basic charged protrusion (circled) that is bulged further away from the helical core of the complex and of the opposite charge as on the counterpart (H3:H4) heterotetramer. (C) Solution measurements of (CENP-A:H4) indicate that it is compacted by $\sim 10 \AA$ relative to its conventional counterpart, as predicted by the compact structure of (CENP-A:H4) in crystal form. The mesh indicates the molecular envelope corresponding to the rotational state that best matches the SAXS data collected for each type of heterotetramer.

(Sekulic et al. 2010). All three distinguishing structural features (hydrophobic stitches, positively charged L1 bulge, and the compaction emanating from its rotated CENPA:CENP-A interface) are encoded by the CENP-A-specific amino acid changes within the CATD. Together with the studies of CENP-A hydrogen/deuterium exchange behavior (Black et al. 2004, 2007a) and functional analysis of the H3 ${ }^{\text {CATD }}$ chimera (Black et al. 2007b), the crystal and solution structural studies (Sekulic et al. 2010) lead to a working model wherein CENP-A marks centromeric chromatin by altering nucleosome structure from within its folded histone core.

\section{REQUIREMENTS FOR INHERITING THE CENTROMERE MARK THROUGH CELL CYCLES}

The structurally divergent CENP-A nucleosome is a prime candidate for the epigenetic propagation of centromere identity. The current view of cell-cycle-coupled centromere inheritance posits that a critical arrangement of CENP-A nucleosomes is sufficient to trigger and propagate a functional centromere. At least three important criteria are likely to be required for epigenetic centromere inheritance. First, the mark must be stable enough to survive through key 
cell cycle steps, including DNA replication and mitotic passage. This property is central to centromere inheritance, but the underlying mechanisms are largely unidentified for any proposed epigenetic mark. Second, centromeric chromatin duplication must be self-templating (e.g., by preexisting chromatin-bound CENP-A molecules). Third, replication of the centromeric mark must be tightly coupled to the cell cycle. Below, we address recent advances in all three of these aspects of epigenetic centromere propagation.

\section{CENTROMERIC CHROMATIN IS STABLE ACROSS MITOTIC DIVISIONS}

Expression shutoff experiments have shown that the total cellular CENP-A pool is turned over at a rate of $\sim 50 \%$ per cell division, suggesting CENP-A to be stably maintained across mitotic division (Shelby et al. 2000; Regnier et al. 2005). To examine the stability of CENP-A after loading into centromeric chromatin, we have used tagging of CENP-A with the $~ 30-k D a$ SNAP-tag, a modified variant of the suicide enzyme $\mathrm{O}^{6}$-alkylguanine-DNA alkyltransferase, whose normal function is in DNA repair. This protein has been extensively engineered to covalently and irreversibly modify (and inactivate) itself through acceptance of the cell-permeable guanine derivative $\mathrm{O}^{6}$-benzylguanine (or fluorescent derivatives thereof). This allows for irreversible fluorescent pulse labeling of SNAP fusion proteins at will in vivo (Keppler et al. 2003, 2004). It is worth noting the specific virtues of the SNAP-tag-based pulselabeling strategy. It stands out from other cell biological tools to determine protein dynamics, such as fluorescence recovery after photobleaching (FRAP) experiments, in that it allows the determination of protein turnover on a much longer timescale (days rather than minutes) and is therefore well suited for proteins with long half-lives.

We applied this methodology to determine CENP-A turnover specifically at centromeres. We showed that nearly all centromeric CENP-A remains centromere-associated during centromeric DNA replication and the subsequent mitosis (Jansen et al. 2007). This extreme stability is consistent with a role for CENP-A as an epigenetic mark maintaining centromere identity. Indeed, following centromeric DNA replication in S phase and chromosome segregation in mitosis, the preexisting "old" (i.e., fluorescently tagged) centromere-bound CENP-A levels were reduced at each daughter centromere to half the level of the unreplicated centromere before DNA replication, strongly suggesting that "old" CENP-A nucleosomes are redistributed during $\mathrm{S}$ phase, with half deposited/redeposited onto each of the replicated DNA copies as the DNA replication fork passes.

\section{CELL CYCLE COUPLING OF CENTROMERIC CHROMATIN REPLICATION}

The twofold dilution of CENP-A nucleosomes during DNA replication indicates that half the CENP-A pool requires replenishment every cell division. Canonical histone expression (including the replication-dependent histone $\mathrm{H} 3$ variant $\mathrm{H3}$.1) is tightly cell-cycle-regulated and restricted to $\mathrm{S}$ phase. Indeed, assembly of histones is directly coupled to the DNA replication machinery, ensuring formation of nascent nucleosomes in the wake of the DNA replication fork (Annunziato 2005; Xu et al. 2010). Given the resemblance of CENP-A to $\mathrm{H} 3$, the question arose how CENP-A assembly is regulated and how this variant is discriminated from canonical $\mathrm{H} 3$ in view of the high levels of H3.1 expression during S phase. Initial models suggested differences in timing of replication of centromeric DNA versus the genome overall as a means to provide a temporal window permissive for CENP-A loading (O'Keefe et al. 1992; Csink and Henikoff 1998). However, subsequent work showed this not to be the case, as replication of centromeric DNA is not restricted to a specific time during $\mathrm{S}$ phase (Shelby et al. 2000).

The attractive alternative would be if CENP-A loading were temporally separated from assembly of canonical histones altogether, with CENP-A assembly outside of $\mathrm{S}$ phase. Indeed, CENP-A mRNA and protein levels peak only after $\mathrm{S}$ phase during late $\mathrm{G}_{2}$, and assembly does not occur simultaneously with DNA replication, which is consistent with a disconnect between the timing of CENP-A and H3 assembly (Shelby et al. 1997, 2000). With our use of SNAP-tagged CENP-A to fluorescently mark only newly synthesized CENP-A, direct evidence in human cells was obtained for replication of centromeric chromatin solely at the exit from mitosis and in early $\mathrm{G}_{1}$ (Jansen et al. 2007), that is, half a cell cycle after centromeric DNA replication (Figs. 4 and 5). Subsequent photobleaching experiments in human cells confirmed this (Hemmerich et al. 2008). A similar conclusion was also reached in Drosophila, where GFP-CENP-A ${ }^{\mathrm{CI}}$ photobleaching experiments in rapidly cycling Drosophila syncytial embryos showed fluorescence recovery during a brief window following mitotic exit concurrent with an increase of overall GFP-CENP-A ${ }^{\text {CID }}$ levels at the centromere (Schuh et al. 2007). Dissociation of cen-

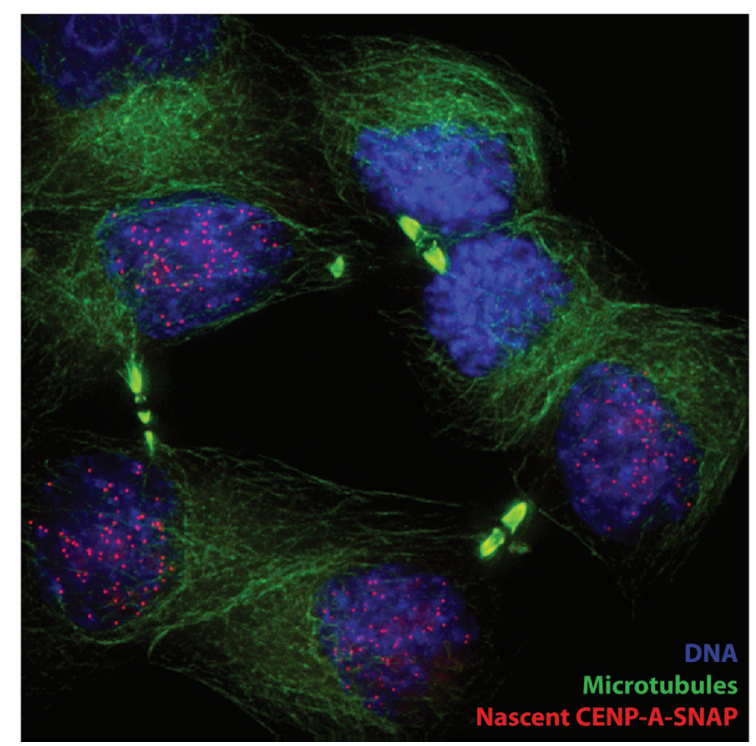

Figure 4. A pool of CENP-A-SNAP, synthesized during S phase, was fluorescently pulse-labeled in $\mathrm{G}_{2}$ phase. Cells were then cycled through mitosis and fixed. Accumulation of nascent CENPA-SNAP (pulse-labeled SNAP, red) at centromeres is evident in cells in late telophase, marked by re-formed nuclei (DNA, blue) and midbodies identifying daughter cells (microtubules, green). 


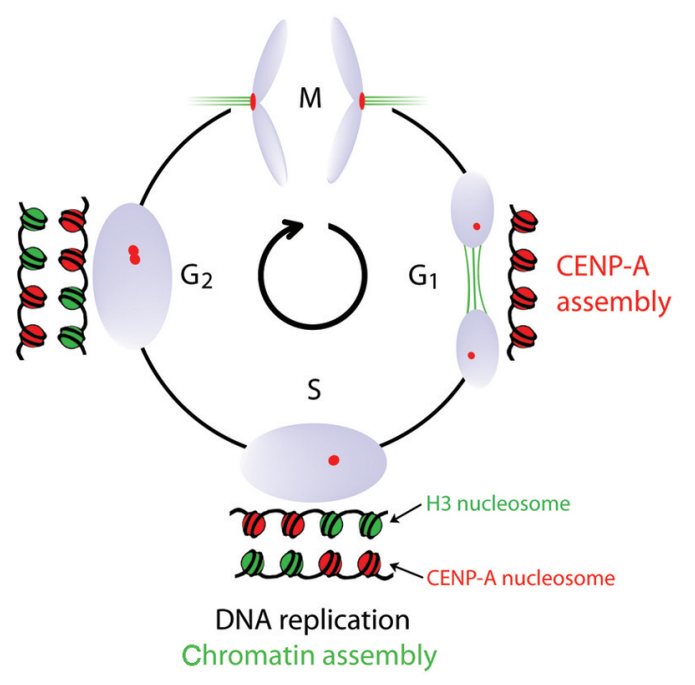

Figure 5. A schematic representation of the temporal uncoupling of DNA replication and canonical chromatin assembly in $\mathrm{S}$ phase from centromeric nucleosome replication in $\mathrm{G}_{1}$.

tromeric DNA replication from that of centromeric chromatin is apparently widespread: In fission yeast cells, CENP-A $\mathrm{A}^{\mathrm{Cnp} 1}$ is assembled in early $\mathrm{S}$ phase, which commences immediately following mitotic exit, suggesting a temporal control similar to that found in higher eukaryotes. However, unlike in fly embryo and human cultured cell examples, there is a second wave of assembly in the fission yeast $\mathrm{G}_{2}$ phase (Takahashi et al. 2005).

\section{FACTORS DIRECTING CENP-A ASSEMBLY IN A TEMPORALLY CONTROLLED MANNER}

The restricted cell cycle window during which CENPA assembly occurs predicts that factors uniquely involved in the delivery and assembly of nascent CENP-A localize to the centromere within the same time frame. Indeed, several components have now been identified that meet this requirement. The most striking member of this group of proteins is Mis18, first identified in fission yeast and shown to be required for CENP-A ${ }^{\text {Cnp1 }}$ localization to the centromere (Hayashi et al. 2004). Mis18 is absent from centromeres during mitosis but rapidly relocalizes to centromeres following mitotic exit. This temporal localization pattern is preserved in a set of human proteins that includes the Mis 18 homologs hMis18 $\alpha$ and hMis $18 \beta$ and the associated protein M18BP1/HsKNL2, which was independently identified as the human homolog of the Caenorhabditis elegans KNL2 protein (Fujita et al. 2007; Maddox et al. 2007). Depletion of any of these proteins severely affects CENP-A localization at the centromere. In this mammalian context, CENP-A recruitment to telophase centromeres closely follows the appearance of Mis18 at the centromere in anaphase (Fujita et al. 2007; Jansen et al. 2007; Maddox et al. 2007; Silva and Jansen 2009). Recent quantitative measurements of CENP-A centromere levels during mitotic exit indicate that CENP-A assembly can initiate as early as $10 \mathrm{~min}$ after anaphase onset, suggesting that the assembly process may be nearly simultaneous with Mis18 recruitment (Lagana et al. 2010). Despite their suggestive localization pattern and role in CENP-A assembly, none of the Mis18 homologs nor M18BP1/HsKNL2 appear to bind to CENP-A directly (Hayashi et al. 2004; Foltz et al. 2006; Fujita et al. 2007; Lagana et al. 2010). In addition, they have not been found in proteomic screens for CENP-A nucleosome or prenucleosome binding factors described below.

\section{RECRUITMENT OF THE CONSTITUTIVE CENTROMERE}

The CENP-A nucleosome forms the basis for a large centromere complex associated with the centromere throughout the cell cycle. The earliest examples of constitutive centromere proteins were identified by human autosera that, in addition to CENP-A, recognized constitutive centromere proteins CENP-B and CENP-C (Earnshaw et al. 1986). Affinity purification of intact CENP-A nucleosomes greatly expanded the knowledge of the protein complement and architecture of the human centromere components most directly bound to CENP-A chromatin (Foltz et al. 2006). Affinity purifications of CENP-A nucleosomes identified a set of known and novel CENP-A nucleosome-associated proteins (CENP-A ${ }^{\mathrm{NAC}}$ ) (Fig. 6), which included CENP-C, $\mathrm{M}, \mathrm{N}, \mathrm{U}$, and T. Subsequent affinity purification of the new proteins within the CENP-A ${ }^{\mathrm{NAC}}$ identified an additional set of constitutive centromere proteins that were associated with the centromere but not themselves associated with the CENP-A nucleosome, called CENP-A distal (CAD) proteins (Foltz et al. 2006; Okada et al. 2006). The CENP-A ${ }^{\text {NAC }}$ and CENP-A $\mathrm{A}^{\mathrm{CAD}}$ have since been collectively termed the constitutive centromere-associated network (CCAN) and can be further subdivided into partially overlapping subcomplexes (Cheeseman et al. 2008; Hori et al. 2008b; Amano et al. 2009). Although recruitment of the CENP$\mathrm{A}^{\mathrm{NAC}}$ is dependent on CENP-A nucleosomes, the assembly of the CENP-A ${ }^{\mathrm{NAC}}$ is also dependent on itself, as elimination of CENP-N, -M, or -T results in the loss of the remaining CENP-A ${ }^{\mathrm{NAC}}$ proteins from the centromere.

Further affinity purification by Fukagawa and colleagues of components bound to CENP-T identified an additional CENP-T binding partner, CENP-W (Hori et al. 2008a). Although CENP-T is clearly associated with and dependent on the CENP-A ${ }^{\mathrm{NAC}}$ for its recruitment, the CENP-T/W complex also interacts with H3-containing chromatin (Foltz et al. 2006; Hori et al. 2008a; Carroll et al. 2010). These data suggest that the CENP-A ${ }^{\mathrm{NAC}}$, in addition to establishing the constitutive centromere at the CENP-A-containing locus, may be capable of organizing the surrounding histone $\mathrm{H} 3$-containing chromatin. Two components identified within the CENP-A ${ }^{\mathrm{NAC}}, \mathrm{CENP}-\mathrm{N}$, and $\mathrm{CENP}-\mathrm{C}$ act as recognition factors that couple the recruitment of the CCAN to the CENP-A nucleosome. CENP-N recognizes the CENP-A nucleosome by virtue of the CATD within CENP-A (Carroll et al. 2009). In contrast, CENP-C is recruited to CENP-A-containing chromatin through an interaction with the extreme carboxyl terminus of CENP-A (Carroll et al. 2010). Because CENP- 

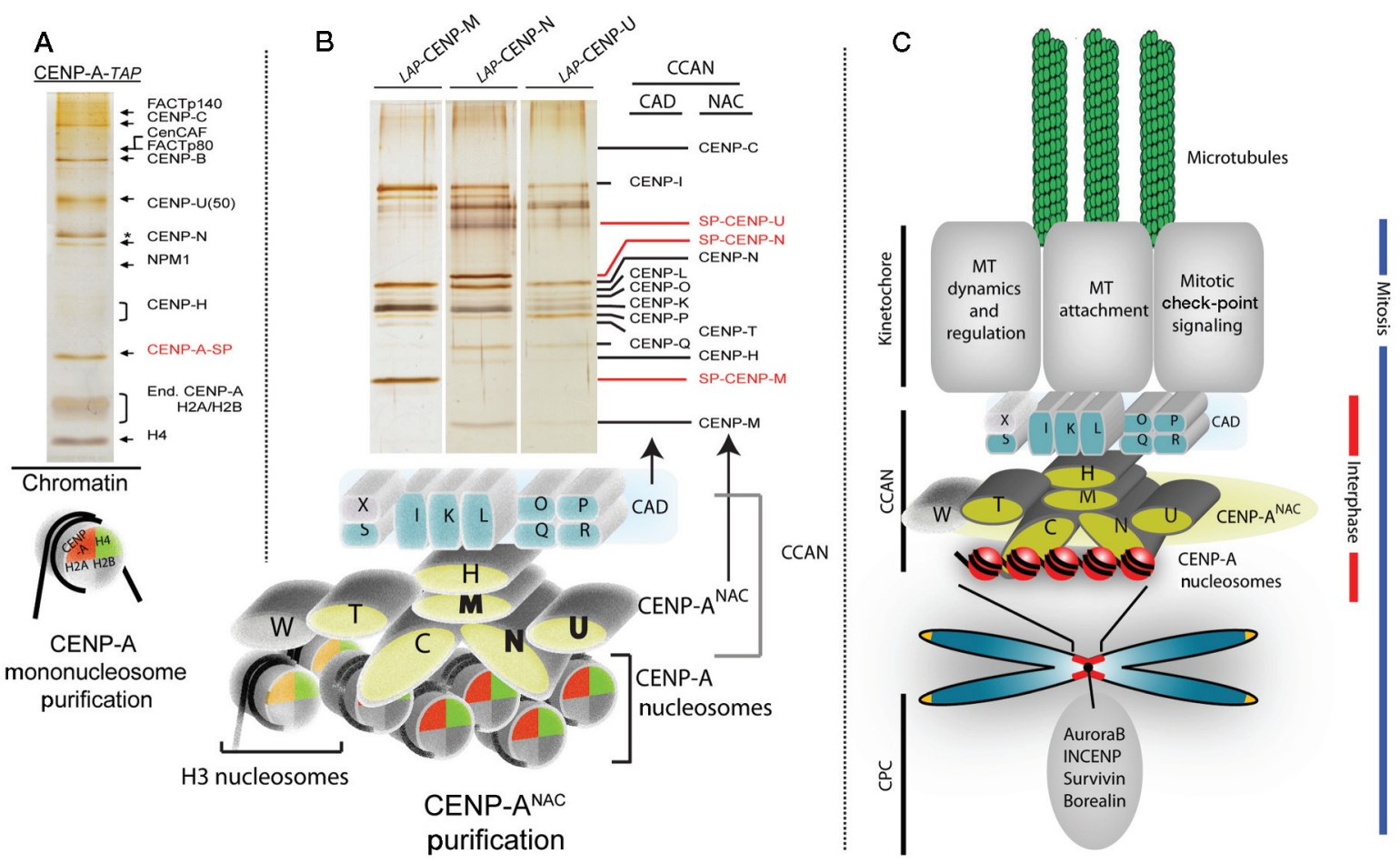

Figure 6. Identification of centromere constituents. $(A)$ Tandem affinity purification was used to identify the set of centromere proteins most closely associated with the CENP-A nucleosome (CENP-A $\left.{ }^{\mathrm{NAC}}\right)$ by affinity purification of intact CENP-A nucleosomes derived from an MNase-digested chromatin fraction. $(B)$ Serial affinity purification of newly identified CENP-A ${ }^{\mathrm{NAC}}$ proteins was used to identify the more distal constitutive components of the centromere that were not in close proximity to the CENP-A nucleosome. (C) Cartoon model of centromere organization from CENP-A nucleosomes to outer kinetochore formation (data adapted from Foltz et al. 2006).

$\mathrm{C}$ and CENP-N recognize distinct domains, they may be able to recognize the same CENP-A nucleosome, although it is unclear whether this occurs in vivo. It is also unclear whether these recognition factors work cooperatively to recruit the CCAN or whether they represent different modes of the CCAN binding to the CENP-A nucleosome that may be used at different times in the cell cycle.

Two other sets set of proteins were copurified with intact CENP-A nucleosomes that were not observed to associate directly with other components of the CCAN-the FACT complex (Obuse et al. 2004; Foltz et al. 2006) and Holliday junction recognition protein (HJURP) (previously termed hFLEG1). As we document below, it is now highly likely that the HJURP protein copurifying with CENP-A nucleosomes represents the fraction of CENPA-containing chromatin that is actively undergoing assembly. The FACT complex has been previously implicated in transcription through chromatinized DNA (Orphanides et al. 1998). FACT activity appears to be important for CENP-A deposition (Okada et al. 2009) and may act to allow access of centromeric assembly factors to the already chromatinized centromere. Recently, by virtue of a human artificial chromosome, it was shown that the centromere has low but detectable levels of active transcription and displays a set of histone modifications that facilitates transcription (Bergmann et al. 2011). Specific removal of one such mark, histone $\mathrm{H} 3$ dimethylated at lysine 4 (H3K4me2), from an engineered centromere se- verely affects centromeric transcription and interferes with recruitment of nascent CENP-A with the concomitant loss of centromeric chromatin structure (Bergmann et al. 2011). Consistent with the presence of FACT, these results suggest that either transcription itself or the chromatin environment it generates helps maintain CENP-A nucleosomes.

\section{IDENTIFICATION OF A CENP-A-SPECIFIC HISTONE CHAPERONE}

The stable propagation of the centromere requires assembly of new CENP-A chromatin/nucleosomes during each cell cycle to avoid the loss of CENP-A nucleosomes through their successive dilution. Epigenetic maintenance of the centromere is therefore dependent on the restricted and targeted assembly of CENP-A into chromatin at the preexisting centromere. In general, nucleosome deposition is regulated by histone chaperone proteins. The histone $\mathrm{H} 3.1$ and H3.3 variants use partially overlapping chaperone complexes to achieve distinct temporal and spatial distributions within the genome. Prenucleosomal histones $\mathrm{H} 3.1$ and $\mathrm{H} 4$ associate with the chromatin assembly factor-1 (CAF-1) complex, consisting of CAF-1 p150, CAF1 p60, and CAF-1 p46/48, and as a dimer with the antisilencing factor 1 chaperone (ASF1) (English et al. 2005; Groth et al. 2007a; Natsume et al. 2007). In contrast, although the histone H3.3 variant also interacts with ASF1 
outside of S phase, it is incorporated into chromatin independent of DNA synthesis through the action of a distinct prenucleosomal complex that includes HIRA and CAF-1 p48 but is devoid of CAF-1 p150 and CAF-1 p60 (Ahmad and Henikoff 2002b; Tagami et al. 2004).

These preceding examples with other histone $\mathrm{H} 3$ variants provided the initial support for a distinct chaperone to achieve centromere-specific deposition of CENP-A. We therefore conducted tandem affinity purification from chromatin-free extracts to identify a prenucleosomal CENP-A complex(es) (Fig. 7). Consistent with a stepwise nucleosome assembly in which the (CENP-A:H4) tetramer is brought to the DNA separately from the H2A:H2B dimer, similar to the assembly steps culminating in conventional nucleosome assembly (Smith and Stillman 1989, 1991; Jackson 1990), we purified a complex that contained CENP-A and histone H4 but was devoid of $\mathrm{H} 2 \mathrm{~A}$ and $\mathrm{H} 2 \mathrm{~B}$. The major unique nonhistone protein associated with prenucleosomal CENP-A was the 83-kDa protein HJURP (Kato et al. 2007; Dunleavy et al. 2009; Foltz et al. 2009). Note that, although HJURP was initially named for its ability to interact with a synthetic Holliday junction in vitro, there is no indication as to whether this property has any relevance to its role as a
CENP-A-specific histone chaperone. HJURP is, however, specifically recruited to centromeres in early $G_{1}$, at the time when new CENP-A nucleosomes are assembled. Furthermore, SNAP-labeling experiments clearly showed that the deposition of new CENP-A nucleosomes is specifically eliminated when HJURP is depleted using siRNA. The interaction between HJURP and CENP-A is mediated by the CENP-A CATD, because swapping of the CATD region into histone $\mathrm{H} 3$ was sufficient for recognition and binding by HJURP (Kato et al. 2007; Dunleavy et al. 2009; Foltz et al. 2009).

The CENP-A prenucleosomal complex also includes two additional proteins - Nucleophosmin1 and RbAp48 (Dunleavy et al. 2009; Foltz et al. 2009). Both proteins were subsequently identified in affinity purifications of HJURP (Shuaib et al. 2010), suggesting that NPM1, RbAp48, HJURP, and CENP-A exist in a common complex. Both RbAp46/48 and NPM1 have proposed roles in assembly of general chromatin. It is likely that HJURP provides the specific assembly of CENP-A into chromatin, and NPM1 and RbAp46/48 may have roles in providing chromatin-remodeling properties of this complex that are required for the deposition of CENP-A nucleosomes into centromeric chromatin, which is likely (but not

A

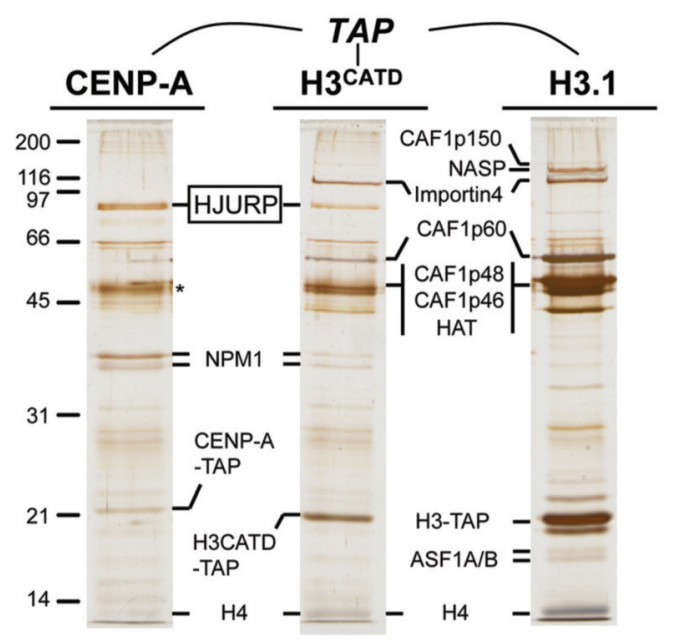

B
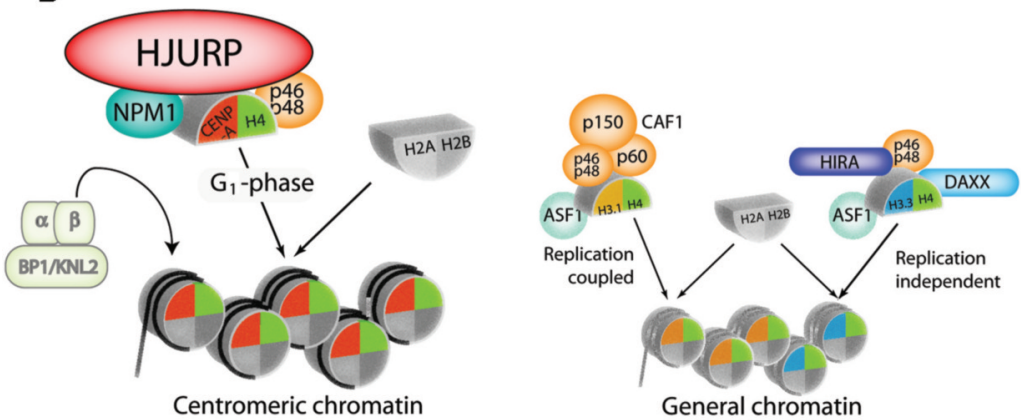

Figure 7. Isolation of prenucleosomal histone complexes. (A) Affinity purifications of CENP-A, H3 ${ }^{\text {CATD }}$, and histone H3.1 were conducted from chromatin-free extracts to identify CENP-A-specific preassembly complexes (data adapted from Foltz et al. 2009). Prenucleosomal CENP-A is uniquely associated with HJURP and NPM1 compared with histone H3.1. The CATD domain of CENP-A mediates the recruitment of HJURP as the H3 ${ }^{\text {CATD }}$ chimeric protein, which is recruited to centromeres, interacts with HJURP. (B) Model of the distinct histone chaperone complexes used by the histone $\mathrm{H} 3$ variants. 
definitively shown) to already contain $\mathrm{H} 3$ histones in the period between centromere DNA replication in $\mathrm{S}$ phase and activation of CENP-A loading at mitotic exit (Fig. 5).

Interestingly, both the epigenetically defined regional centromere of Schizosaccharomyces pombe and the genetically encoded point centromere of Saccharomyces cerevisiae require the HJURP homolog $\mathrm{Scm} 3$ for the assembly of CENP-A onto centromeres (Mizuguchi et al. 2007; Camahort et al. 2009; Pidoux et al. 2009; Williams et al. 2009). The timing of centromeric association differs: In fission yeast, $\mathrm{Scm} 3$ is present at the yeast centromere during the majority of the cell cycle but clearly absent during mitosis (Pidoux et al. 2009; Williams et al. 2009), a much more expanded time frame than that observed in vertebrate cells, where HJURP recruitment is restricted to early $\mathrm{G}_{1}$ (Fig. 5). For budding yeast, the situation is highly controversial. One hypothesis is for an unusual CENP$\mathrm{A}^{\mathrm{Cse} 4}$ hexomeric "nucleosome" in which $\mathrm{Scm} 3$ replaces H2A and H2B (Mizuguchi et al. 2007). Another hypothesis proposes an $\mathrm{Scm} 3$-containing trisome of CENP-A ${ }^{\mathrm{Cse} 4}$, $\mathrm{H} 4$, and $\mathrm{Scm} 3$ with right-handed DNA wrapping (Furuyama and Henikoff 2009), and one final proposal is for more conventional octameric nucleosomes (Camahort et al. 2009). As we argue elsewhere (Black and Cleveland 2011), a plausible, partial resolution of these conflicting claims could be that one or more of these represent CENP$\mathrm{A}^{\mathrm{Cse} 4}$ chromatin at different points in the budding yeast cell cycle.

Assembly of histone H3.1 nucleosomes is coupled to replication. This is achieved through interaction between histone H3.1 and the MCM replicative helicase and between CAF1p150 and PCNA (Shibahara and Stillman 1999; Moggs et al. 2000; Groth et al. 2007b). Both PCNA and CAF1p150 are major components of the replication machinery, such that new histone H3.1 nucleosome assembly occurs in close proximity to DNA synthesis. Exactly how CENP-A assembly is coupled to existing centromeres is not yet understood. One hypothesis is that preexisting CENP-A nucleosomes direct the incorporation of new CENP-A nucleosomes either directly or through the recruitment of intermediate factors. These factors could include the covalent modification of surrounding centromeric chromatin, or one or more members of the CCAN could play this part. In turn, HJURP must recognize either the existing CENP-A nucleosome or the intermediate factors or modifications they induce to direct the assembly of new CENP-A nucleosomes.

Purifications of prenucleosomal or nucleosomal CENPA and HJURP have failed to identify a mammalian Mis18 homolog, and likewise, HJURP and CENP-A are not evident in purifications of the members of the Mis18 complex, as mentioned above. This finding has led to the hypothesis that the Mis18 complex is required for priming the centromere in preparation for HJURP-mediated CENPA nucleosome assembly (Fujita et al. 2007; Silva and Jansen 2009). Other factors with roles in CENP-A assembly may include Rsf-1 and SNF2h, both of which are part of the remodeling and spacing factor (RSF) complex. This chromatin-targeted ATPase has been implicated in CENPA assembly and suggested to participate in the nucleosome incorporation step (Perpelescu et al. 2009). In addition, the small GTPase-activating protein MgcRacGAP, previously implicated in cyctokinesis, has now been identified as a component involved in CENP-A assembly (Lagana et al. 2010). Strikingly, Rsf-1 and MgcRacGAP along with one of its targets, Cdc42, in human cells localize to centromeres during mid and late $\mathrm{G}_{1}$, respectively (Perpelescu et al. 2009; Lagana et al. 2010). Although it is unclear to what extent these processes are temporally distinct and to what aspect of centromeric CENP-A metabolism they contribute, it appears likely that the incorporation of new CENP-A into centromeric chromatin is a multistep process that may span several hours. In agreement with this notion, quantitative fluorescent measurements of centromeric CENP-A levels indicate that, although CENP-A assembly initiates in early $\mathrm{G}_{1}$, accumulation of CENP-A can continue for up to $10 \mathrm{~h}$ in human HeLa cells (Lagana et al. 2010).

\section{ALTERNATE FORMS OF CENTROMERIC NUCLEOSOMES: VERDICT IS STILL OUT}

Although several studies have supported the notion that CENP-A is present at the centromere in octameric nucleosomes ([CENP-A:H4:H2A:H2B $]_{2}+$ DNA) in which it replaces both copies of H3 (Shelby et al. 1997; Foltz et al. 2006; Camahort et al. 2009), several other proposals (some introduced above) have been put forward (Dalal et al. 2007; Mizuguchi et al. 2007; Furuyama and Henikoff 2009; Lavelle et al. 2009; Williams et al. 2009). Of these proposals, some are likely to represent $\mathrm{G}_{1}$ assembly intermediates in the assembly/maturation of centromere-specifying nucleosomes, involving either the absence (Williams et al. 2009) or replacement of $\mathrm{H} 2 \mathrm{~A} / \mathrm{H} 2 \mathrm{~B}$ dimers with the putative chromatin assembly protein Scm3/HJURP (Mizuguchi et al. 2007).

A much more unconventional challenge to an octameric configuration has come from Henikoff and colleagues with the initial proposal that CENP-A exists at centromeres in a hemisomal configuration with one copy each of CENP-A, H4, H2A, and H2B (Dalal et al. 2007) and extended more recently to include a model of right-handed DNA wrapping (Furuyama and Henikoff 2009), opposite of the left-handed wrapping that induces negative supercoils following conventional nucleosome assembly into closed, circular DNA. Initial findings interpreted to support the hemisome proposal emerged from atomic force microscopy (AFM) evidence that CENP-A ${ }^{\mathrm{Cid}}$ chromatin purified from Drosophila cells (Dalal et al. 2007) (and recently extended to CENP-A-containing material derived from mammalian [HeLa] cells [Dimitriadis et al. 2010]) indicate that immunopurified CENP-A chromatin is half the height of the major nucleosome conformation observed in unpurified bulk chromatin.

It is important to note that the hemisome model conflicts with data from structural and functional studies that indicate that the CENP-A/CENP-A interface, completely absent in a hemisome model, is an essential feature of a CENP-A-containing nucleosome (Camahort et al. 2009; Sekulic et al. 2010), even conferring specificity for a ho- 
A

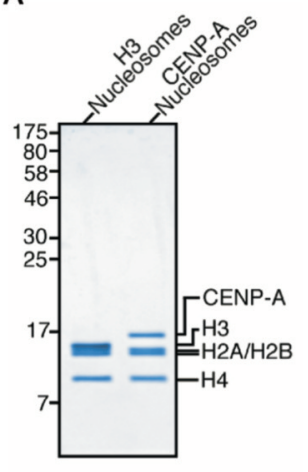

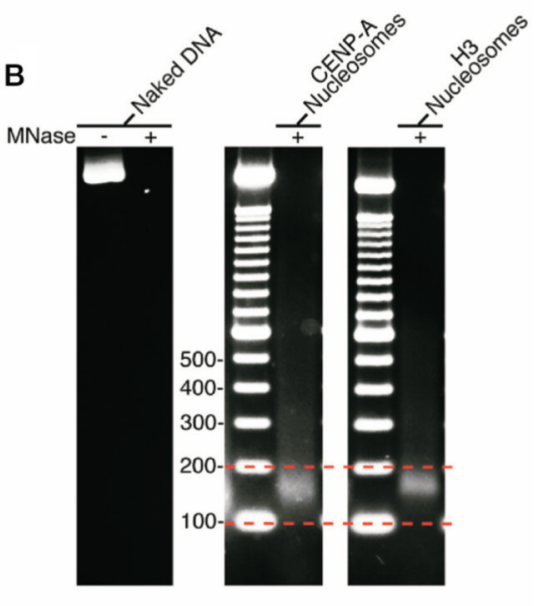

C

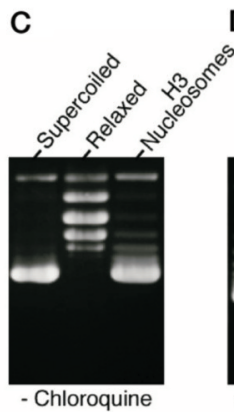

D

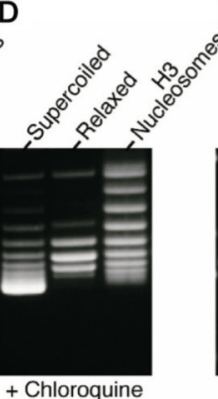

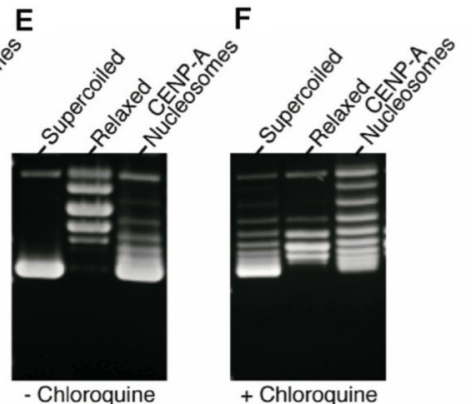

Figure 8. CENP-A assembles into octameric nucleosomes with conventional left-handed DNA wrapping (data adapted from Sekulic et al. 2010). (A) Histone content of assembled H3- and CENPA-containing nucleosomes. $(B)$ Digestion of nucleosome arrays with micrococcal nuclease reveals that both H3- and CENP-A-containing nucleosomes protect $\sim 150 \mathrm{bp}$ of DNA. $(C-F)$ Topological analysis of H3- $(C, D)$ and CENP-A-containing $(E, F)$ nucleosomes. Analysis by gel electrophoresis in the absence $(C, E)$ or presence $(D, F)$ of chloroquine reveals that both $\mathrm{H} 3$ - and CENP-A-containing nucleosomes wrap DNA in a left-handed manner. motypic (two copies of CENP-A) versus a heterotypic (one copy each, CENP-A and H3) nucleosome (in the case of budding yeast) (Kingston et al. 2011). Indeed, human CENP-A self-assembles with histones H2A, H2B, and H4 into octameric nucleosomes that protect $\sim 150 \mathrm{bp}$ of DNA from nuclease digestion and wrap DNA with the conventional left-handedness, inducing negative supercoils into DNA (Fig. 8) (Sekulic et al. 2010).

Beyond the structural evidence against the hemisome model, there are also plausible alternative interpretations of the primary evidence (intranucleosomal chemical crosslinking [Dalal et al. 2007], atomic force microscopy [Dalal et al. 2007], and apparent handedness of DNA supercoiling [Furuyama and Henikoff 2009]) that support the hemisome model (Black and Bassett 2008; Lavelle et al. 2009):

1. The cross-linking experiments were done with dimethyl suberimidate, something used early on in nucleosome studies to define the oligomeric state of purified subnucleosomal (H3:H4) heterotetramers and $\mathrm{H} 2 \mathrm{~A}: \mathrm{H} 2 \mathrm{~B}$ heterodimers (Kornberg and Thomas 1974). This linker has an $11 \AA$ spacer arm and interacts with primary amines. Within conventional nucleosomes, most of the interhistone cross-links are between $\mathrm{H} 2 \mathrm{~B}$ and the other histones (H2A, H3, and H4) within "half" of the nucleosomes, with cross-links at the interface between H3:H3 less efficient (Suda and Iwai 1979). The H3:H3 cross-links very likely come from lysines at positions 115 and 122 (K115 and K115' are $\sim 8 \AA$ apart, K115 and $\mathrm{K} 122^{\prime}$ are $\sim 5 \AA$ apart, and K122 and K122' are $\sim 15$ $\AA$ apart, with side chains facing each other in each case)
(Luger et al. 1997). The Drosophila CENP-A ${ }^{\mathrm{CID}}$ used in the cross-linking studies lacks these lysines, and the nearest residue with a cross-linkable side chain is a lysine at the position corresponding to I112 in H3. For this pair of lysines at the putative CID:CID interface, the lysines are predicted to be $\sim 20 \AA$ apart and oriented so that their side chains are in opposite directions (Luger et al. 1997). Less efficient cross-linking of an octameric species, in the case of CID nucleosomes, is therefore the expected result, even if they exist in an octameric form with two copies of CID.

2. Interpreting the "height" of DNA complexes with AFM is not as straightforward as it initially seems. Well-established AFM distortions measure the height of double-stranded DNA at $0.5-0.8 \mathrm{~nm}$, instead of its native 2.0-2.5-nm diameter (Dalal et al. 2007; Klinov et al. 2009). Furthermore, because there is no additional height reported from copurifying centromere components (e.g., CENP-B, CENP-C, and presumably other CCAN components), the $~ 1.7-n m$ CENP-A nucleosome height and the $\sim 3.5-\mathrm{nm}$ bulk chromatin nucleosome height (Dalal et al. 2007; Dimitriadis et al. 2010) are each likely primarily contributed by the number of DNA wraps/crosses, not the protein constituents. Although height difference has been interpreted as evidence for a hemisome, it is also consistent with changes in DNA wrapping within an octameric nucleosome occurring during CENP-A nucleosome immunopurification (Dalal et al. 2007; Dimitriadis et al. 2010), either as a consequence of proposed changes of 
nucleosome shape (Sekulic et al. 2010) or as a function of actual differences in DNA wrapping in native chromatin. To the latter point, reconstituted CENP-A nucleosomes do not favor the conventional crossed DNA at the entry/exit site and likewise also disfavor linker histone binding (Conde e Silva et al. 2007). The altered DNA crossing arises from weakening of the interaction between the $\alpha \mathrm{N}$ helix of human CENP-A and the entry/exit DNA that fails to clamp the final turn of nucleosomal DNA, as well as the corresponding $\alpha \mathrm{N}$ helix of H3 (Conde e Silva et al. 2007). Similar loss of tight binding at the DNA entry/exit site is also the case for budding yeast CENP-A, which forms octameric nucleosomes that wrap only 125 bp of DNA (i.e., approximately one turn of DNA missing at each DNA entry/exit site) (Kingston et al. 2011).

3. For the in vitro supercoiling experiments that were interpreted to indicate unconventional right-handed DNA wrapping of CENP-A ${ }^{\mathrm{Cid}}$-containing nucleosomes, Prunell and colleagues (Lavelle et al. 2009) have argued that there are equally plausible, alternative interpretations. Included here are unconventional intra- and interhistone particle interactions of one type or a mixture of tetrasomes (CENP-A:H4) ${ }_{2}$, hexasomes (CENP-A:H4) (H2A:H2B), or octameric nucleosomes (CENP-A:H4: H2A:H2B) ${ }_{2}$. As an example of this, Lavelle et al. (2009) have pointed out that archael HMf histones induce negative supercoils when assembled onto DNA as a single particle but probably have higher-order interactions that trap positive supercoils on multiparticle arrays such as those used for Drosophila CID (Furuyama and Henikoff 2009). In addition, Lavelle et al. (2009) note that generic histone chaperones (e.g., Nap1 or RbAp48 used by Furuyama and Henikoff [2009]) are prone to promoting misassembly into a mixture of subnucleosomal particles whose interactions can generate negative or positive supercoiling. Without knowing either the regularity (or irregularity) or histone stoichiometry of the CID-containing structures assembled onto closed, circular DNA (as is the case for the evidence of Furuyama and Henikoff [2009]), it is not possible to determine the mode by which positive supercoils were generated.

4. Perhaps the most persuasive of the evidence for righthanded DNA wrapping in centromeric chromatin was the loss, when functional centromere sequences were included, of two negative supercoils on a budding yeast minichromosome of a size that could accommodate nine conventional yeast nucleosomes (Furuyama and Henikoff 2009). Rather than positive supercoiling at the centromere, the reduction in negative supercoiling could also indicate that the inclusion of a centromere and the centromere proteins and cohesins recruited to it sterically blocks assembly of more than one adjacent conventional nucleosome (and the negative supercoils they impart). This latter interpretation is firmly supported by the DNase sensitivity known to flank yeast centromeres (Bloom and Carbon 1982) and the major higher-order conformational alterations that yeast centromeres impart to such minichromosomes (Surcel et al. 2008).
In sum, the issue of whether CENP-A marks centromeres by conferring distinguishing physical properties to octameric nucleosomes into which it assembles (Black et al. 2007a; Sekulic et al. 2010) or whether (and if so, how) it somehow overcomes its intrinsic spontaneous assembly into octameric nucleosomes in favor of a hemisome (Dalal et al. 2007; Furuyama and Henikoff 2009) awaits future definitive experimentation. In this vein, it is important to remember that hemisomes/nucleosomes were debated in the 1970s for conventional nucleosomes (e.g., see Weintraub et al. 1976), and many complementary approaches with native chromatin and purified components were required to form our current view of the relevant major nucleosomal form in chromatin.

\section{CLOSURE OF EPIGENETIC FEEDBACK LOOP: MODEL FOR CENP-A TARGETING TO THE CENTROMERE}

CENP-A assembly at centromeres in human cells is affected not only by the $\mathrm{G}_{1}$-phase-specific residents described above (Mis18 complex [Fujita et al. 2007; Maddox et al. 2007] and HJURP [Dunleavy et al. 2009; Foltz et al. 2009]) but also by members of the constitutive centromere complex (CCAN) and the Mis12 complex (Kline et al. 2006; Okada et al. 2006; Carroll et al. 2010). Merging all of these findings supports a model in which the CENP-A prenucleosome complex is targeted to centromeres by HJURP through an interaction either with constitutive centromere components or by binding the Mis 18:KNL2 proteins (Fig. 9). There is some support for the latter possibility in fission yeast. $\mathrm{Scm} 3^{\mathrm{Sp}}$ interacts with Mis18 in pull-downs as well as in vitro assays, potentially providing a molecular link between CENP-A and the Mis18 proteins (Pidoux et al. 2009).

How then are the Mis18:KNL2 proteins targeted to the centromeres? The human Mis18: KNL2 proteins arrive at the centromere in a manner that is largely unaffected by RNAi-mediated knockdown of CENP-A protein (Hayashi et al. 2004; Fujita et al. 2007). Consistent with this, M18BP1/KNL2 protein harbors a divergent Myb/SANT domain (Boyer et al. 2004; Maddox et al. 2007), suggesting that the complex may be targeted directly to DNA or histone tails. Perhaps the Mis18:KNL2 proteins may target to centromeres somewhat distal from CENP-A nucleosomes and "license" the centromere for recruitment of new CENP-A nucleosomes. In human cells, the consequences of hMis $18 \alpha$ depletion apparently can be partially alleviated by experimentally increasing global acetylation levels (Fujita et al. 2007), consistent with acetylation of an as-of-yet-unknown target as a central step involved in centromere licensing for CENP-A assembly.

How the HJURP:CENP-A:H4 complex targets to the centromere in human $G_{1}$ cells is unknown. Members of the CCAN would be potential candidates. In light of this, it is noteworthy that the constitutive centromere protein CENP-N not only binds to CENP-A nucleosomes directly but also affects CENP-A assembly (Carroll et al. 2010). This may represent an epigenetic feedback loop in which the reader (CENP-N) of the epigenetic mark (the CENP- 


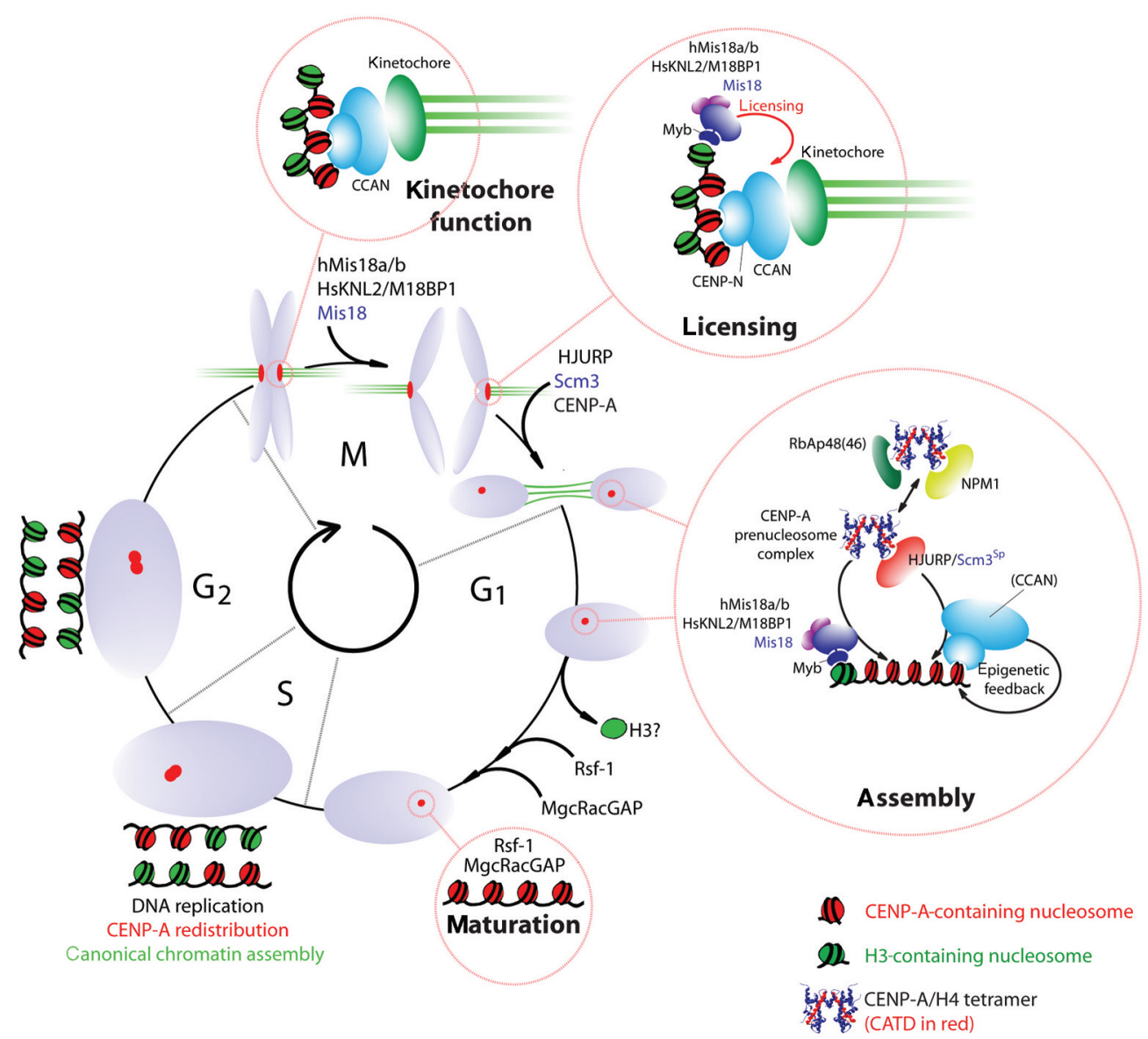

Figure 9. Model representing the centromeric chromatin cycle. CENP-A-containing nucleosomes are redistributed during DNA replication in $\mathrm{S}$ phase. The resulting mixed CENP-A/H3 chromatin supports kinetochore formation during mitosis. An unknown mitotic signal triggers "licensing" of centromeres by Mis18:KNL2 proteins in anaphase for subsequence assembly of CENP-A. The molecular nature of the licensing step is unknown but likely precedes recruitment of CENP-A as a separate step. Assembly of new CENP-A is mediated by the HJURP-containing prenucleosomal complex throughout the first hours of $\mathrm{G}_{1}$. Targeting of the prenucleosomal complex may involve the Mis 18:KNL2 proteins or CCAN members. Assembly of CENP-A is predicted to involve exchange of $\mathrm{H} 3$ from centromeric chromatin and may require additional activities provided by the RSF complex and the small GTPase-activating protein MgcRacGAP in late $\mathrm{G}_{1}$ (provisionally termed "maturation").

A nucleosome) contributes to the propagation of that mark. This may explain, in part, how epigenetic centromere identity provided by the CENP-A nucleosome is transferred to the next generation of nucleosomes in subsequent cell divisions (Fig. 9).

\section{IMPLICATIONS OF G CENP-A $_{1}$ ASSEMBLY FOR CENTROMERE FUNCTION AND INHERITANCE}

The abrupt onset of CENP-A assembly into centromeric chromatin exclusively after reentry into $\mathrm{G}_{1}$, but not in mitosis, has important implications for epigenetic centromere inheritance. First, the temporal disconnect between CENP-A assembly in $\mathrm{G}_{1}$ and histone $\mathrm{H} 3$ loading in bulk chromatin in $\mathrm{S}$ phase may contribute to providing specificity in the assembly of these related histone $\mathrm{H} 3$ family members. Second, loading of new CENP-A following mitosis dictates that centromeres and the kinetochores assembled on them proceed through mitosis with only half the complement of CENP-A. During S phase, CENP-A protein is diluted among sister centromeres, leaving CENP-A missing from half the DNA sequences occupied by it before DNA replication. What protein complexes are loaded onto these sites has not been established, although it seems most likely that they are occupied by typical histone H3.1-containing nucleosomes, which are available in excess during DNA replication.

In agreement with this view, histone $\mathrm{H} 3$-containing nucleosomes have been detected on mitotic centromeres interspersed with CENP-A-containing nucleosomes and have been shown to occupy centromeric chromatin when CENP-A levels are depleted (Blower et al. 2002; Sullivan and Karpen 2004). $G_{1}$ assembly of CENP-A directly suggests that $\mathrm{H} 3$ found interspersed with CENP-A on mitotic chromosomes may represent the pool that acts as a placeholder for exchange with CENP-A later. In this way, H3 represents an integral part of mitotic centromeric chromatin that may help promote kinetochore formation during mitosis. Indeed, although the constitutive centromere 
proteins CENP-T and CENP-W depend on CENP-A for their association with centromeres, they also make direct contacts with H3-containing nucleosomes (Hori et al. 2008a; Ribeiro et al. 2010).

\section{UNRESOLVED: WHAT ACTIVATES CENTROMERIC CHROMATIN REPLICATION AT EXIT FROM MITOSIS?}

The onset of CENP-A assembly at centromeres at the end of mitosis firmly supports a model in which loading of CENP-A requires inactivation of one or more inhibitors at mitotic exit or activation of one or more key components by entry into early $G_{1}$. An early proposal hypothesized a role for microtubule-mediated tension generated across centromeric chromatin in signaling CENP-A assembly (Ahmad and Henikoff 2002a; Mellone and Allshire 2003; Allshire and Karpen 2008). This possibility has been disproven, at least in a strict sense, because exit from mitosis in which all kinetochore-microtubule attachment was blocked still triggered comparable CENP-A loading at centromeres in the subsequent $\mathrm{G}_{1}$ (Jansen et al. 2007; Schuh et al. 2007). A role for a putative diffusible, cytoplasmic factor sufficient to trigger CENP-A assembly has also been eliminated by cell-cell fusion experiments in which $\mathrm{G}_{2}$-phase cells were fused to $\mathrm{G}_{1}$-phase cells. Under those conditions, the $\mathrm{G}_{1}$-derived nucleus was proficient in assembly of new CENP-A, whereas the $\mathrm{G}_{2}$-derived nucleus was not, despite bearing a nascent, unloaded pool of CENP-A and sharing the same cytoplasm with the actively loading $\mathrm{G}_{1}$ nucleus (Jansen et al. 2007).

A highly selective screen for factors that affect CENPA levels at the centromere in Drosophila tissue culture cells identified four components, two of which are cell cycle regulators, Cyclin A and RCA1 (known as Emi1 in mammalian cells) (Erhardt et al. 2008). Both of these factors negatively regulate the anaphase-promoting complex (APC) activity before mitosis (Zachariae et al. 1998; Di Fiore and Pines 2007). Although an $\mathrm{S} / \mathrm{G}_{2}$ arrest and concurrent endoreduplication (which results from depletion of either of these factors) were ruled out as the cause for CENP-A ${ }^{\mathrm{CID}}$ delocalization, it is not at all obvious how inhibition of APC activity would positively influence CENPA assembly. Nevertheless, a report of a proportion of cyclin A bound at centromeres has implicated this factor in centromere maintenance in a direct manner (Erhardt et al. 2008), albeit this too is perplexing as cyclin A is destroyed midway through mitosis, yet CENP-A loading is delayed until earliest $\mathrm{G}_{1}$.

In sum, the critical signal to initiate postmitotic centromeric chromatin replication remains to be identified. Possibilities include that CENP-A assembly and/or the recruitment of assembly factors at the centromere are dependent on (1) conditioning of chromatin during mitosis (Mellone and Allshire 2003; Jansen et al. 2007); (2) nuclear envelope breakdown, thereby allowing access to chromatin of a specific assembly factor; (3) kinetochore assembly and/or disassembly (Jansen et al. 2007; Allshire and Karpen 2008); or (4) mitotic modification of CENP-A itself. Any of these could create an environment that is permissive for subsequent CENP-A loading. An additional possibility is that components of the greater centromere/ kinetochore (and which are therefore recruited in a CENP-A-dependent manner) may, in turn, affect CENP-A loading or stabilization after loading. Indeed, defects in structural centromere proteins have been shown to affect CENP-A levels, which includes proteins that assemble during mitosis (Kline et al. 2006; Okada et al. 2006; Carroll et al. 2010).

\section{OUTLOOK}

The centromere is the chromosomal element whose job is to ensure faithful Mendelian inheritance of chromosomes; yet, the molecular basis for specifying centromere identity and its maintenance through generations is just now being uncovered. Although substantial progress has been made in determining how CENP-A physically marks the chromatin into which it assembles, defining when newly expressed CENP-A is deposited into centromeric chromatin each cell cycle, and identifying the proteins recruited to centromeric nucleosomes and those that chaperone newly made CENP-A to the centromeres, major issues remain to be resolved for understanding how centromeres are epigenetically replicated every cell cycle (Fig. 9). Issues of immediate attention are resolving what are the major oligomeric form(s) of CENP-A nucleosomes through the cell cycle, characterizing the regulatory mechanisms that restrict newly expressed CENP-A centromere deposition to $G_{1}$, and understanding the precise role of the HJURP chaperone in the assembly reaction that culminates in deposition of CENP-A into centromeric chromatin.

\section{ACKNOWLEDGMENTS}

This work was supported by grants from the National Institutes of Health to B.E.B. (GM82989) and D.W.C. (GM74150); the American Cancer Society to D.R.F. (RSG-09-165-01); and the Fundação Calouste Gulbenkian, the Fundação para a Ciência e a Tecnologia (BIA-BCM/100557/2008 and BIA-PRO/100537/2008), the European Commission FP7 programme, and an EMBO installation grant to L.E.T.J. B.E.B. is also supported by a Career Award in the Biomedical Sciences from the Burroughs Wellcome Fund and a Rita Allen Foundation Scholar Award. D.W.C. receives salary support from the Ludwig Institute for Cancer Research. We thank E. Bassett, N. Sekulic, and S. Wood from the Black laboratory for providing data figures.

\section{REFERENCES}

Ahmad K, Henikoff S. 2002a. Histone H3 variants specify modes of chromatin assembly. Proc Natl Acad Sci 99: 16477-16484.

Ahmad K, Henikoff S. 2002b. The histone variant H3.3 marks active chromatin by replication-independent nucleosome assembly. Mol Cell 9: 1191-1200.

Allshire RC, Karpen GH. 2008. Epigenetic regulation of centromeric chromatin: Old dogs, new tricks? Nat Rev Genet 9: 923-937.

Amano M, Suzuki A, Hori T, Backer C, Okawa K, Cheeseman IM, Fukagawa T. 2009. The CENP-S complex is essential for the 
stable assembly of outer kinetochore structure. J Cell Biol 186: 173-182.

Amor DJ, Bentley K, Ryan J, Perry J, Wong L, Slater H, Choo KH. 2004. Human centromere repositioning "in progress." Proc Natl Acad Sci 101: 6542-6547.

Annunziato AT. 2005. Split decision: What happens to nucleosomes during DNA replication? J Biol Chem 280: 12065-12068.

Bassett EA, Wood S, Salimian KJ, Ajith S, Foltz DR, Black BE. 2010. Epigenetic centromere specification directs Aurora B accumulation but is insufficient to efficiently correct mitotic errors. J Cell Biol 190: 177-185.

Bergmann JH, Rodriguez MG, Martins NM, Kimura H, Kelly DA, Masumoto H, Larionov V, Jansen LE, Earnshaw WC. 2011. Epigenetic engineering shows $\mathrm{H} 3 \mathrm{~K} 4 \mathrm{me} 2$ is required for HJURP targeting and CENP-A assembly on a synthetic human kinetochore. EMBO J 30: 328-340.

Black BE, Bassett EA. 2008. The histone variant CENP-A and centromere specification. Curr Opin Cell Biol 20: 91-100.

Black BE, Cleveland DW. 2011. Epigenetic centromere propagation and the nature of CENP-A nucleosomes. Cell 144: 471-479.

Black BE, Foltz DR, Chakravarthy S, Luger K, Woods VL, Cleveland DW. 2004. Structural determinants for generating centromeric chromatin. Nature 430: 578-582.

Black BE, Brock MA, Bédard S, Woods VL, Cleveland DW. 2007a. An epigenetic mark generated by the incorporation of CENP-A into centromeric nucleosomes. Proc Natl Acad Sci 104: 5008-5013.

Black BE, Jansen LET, Maddox PS, Foltz DR, Desai AB, Shah JV, Cleveland DW. 2007b. Centromere identity maintained by nucleosomes assembled with histone $\mathrm{H} 3$ containing the CENP-A targeting domain. Mol Cell 25: 309-322.

Bloom KS, Carbon J. 1982. Yeast centromere DNA is in a unique and highly ordered structure in chromosomes and small circular minichromosomes. Cell 29: 305-317.

Blower MD, Sullivan BA, Karpen GH. 2002. Conserved organization of centromeric chromatin in flies and humans. Dev Cell 2: 319-330.

Boyer LA, Latek RR, Peterson CL. 2004. The SANT domain: A unique histone-tail-binding module? Nat Rev Mol Cell Biol 5: $158-163$.

Buchwitz BJ, Ahmad K, Moore LL, Roth MB, Henikoff S. 1999. A histone-H3-like protein in C. elegans. Nature 401: 547-548.

Camahort R, Shivaraju M, Mattingly M, Li B, Nakanishi S, Zhu D, Shilatifard A, Workman JL, Gerton JL. 2009. Cse4 is part of an octameric nucleosome in budding yeast. Mol Cell 35: 794805 .

Carbone L, Nergadze SG, Magnani E, Misceo D, Francesca Cardone M, Roberto R, Bertoni L, Attolini C, Francesca Piras M, de Jong P, et al. 2006. Evolutionary movement of centromeres in horse, donkey, and zebra. Genomics 87: 777-782.

Carroll CW, Silva MC, Godek KM, Jansen LE, Straight AF. 2009. Centromere assembly requires the direct recognition of CENPA nucleosomes by CENP-N. Nat Cell Biol 11: 896-902.

Carroll CW, Milks KJ, Straight AF. 2010. Dual recognition of CENP-A nucleosomes is required for centromere assembly. $J$ Cell Biol 189: 1143-1155.

Cheeseman IM, Hori T, Fukagawa T, Desai A. 2008. KNL1 and the CENP-H/I/K complex coordinately direct kinetochore assembly in vertebrates. Mol Biol Cell 19: 587-594.

Choo KH. 2001. Domain organization at the centromere and neocentromere. Dev Cell 1: 165-177.

Clarke L, Carbon J. 1980. Isolation of a yeast centromere and construction of functional small circular chromosomes. Nature 287: 504-509.

Conde e Silva N, Black BE, Sivolob A, Filipski J, Cleveland DW, Prunell A. 2007. CENP-A-containing nucleosomes: Easier disassembly versus exclusive centromeric localization. $J \mathrm{Mol}$ Biol 370: $555-573$.

Csink AK, Henikoff S. 1998. Something from nothing: The evolution and utility of satellite repeats. Trends Genet 14: 200-204.

Dalal Y, Wang H, Lindsay S, Henikoff S. 2007. Tetrameric structure of centromeric nucleosomes in interphase Drosophila cells. PLoS Biol 5: e218. doi: 10.1371/journal.pbio.0050218.
Depinet TW, Zackowski JL, Earnshaw WC, Kaffe S, Sekhon GS, Stallard R, Sullivan BA, Vance GH, Van Dyke DL, Willard HF, et al. 1997. Characterization of neo-centromeres in marker chromosomes lacking detectable alpha-satellite DNA. Hum Mol Genet 6: 1195-1204.

Di Fiore B, Pines J. 2007. Emi1 is needed to couple DNA replication with mitosis but does not regulate activation of the mitotic APC/C. J Cell Biol 177: 425-437.

Dimitriadis EK, Weber C, Gill RK, Diekmann S, Dalal Y. 2010. Tetrameric organization of vertebrate centromeric nucleosomes. Proc Natl Acad Sci 107: 20317-20322.

Dunleavy EM, Roche D, Tagami H, Lacoste N, Ray-Gallet D, Nakamura Y, Daigo Y, Nakatani Y, Almouzni-Pettinotti G. 2009. HJURP is a cell-cycle-dependent maintenance and deposition factor of CENP-A at centromeres. Cell 137: 485-497.

du Sart D, Cancilla MR, Earle E, Mao JI, Saffery R, Tainton KM, Kalitsis P, Martyn J, Barry AE, Choo KH. 1997. A functional neo-centromere formed through activation of a latent human centromere and consisting of non-alpha-satellite DNA. Nat Genet 16: 144-153.

Earnshaw WC, Migeon BR. 1985. Three related centromere proteins are absent from the inactive centromere of a stable isodicentric chromosome. Chromosoma 92: 290-296.

Earnshaw WC, Rothfield N. 1985. Identification of a family of human centromere proteins using autoimmune sera from patients with scleroderma. Chromosoma 91: 313-321.

Earnshaw W, Bordwell B, Marino C, Rothfield N. 1986. Three human chromosomal autoantigens are recognized by sera from patients with anti-centromere antibodies. J Clin Invest 77: 426430.

English CM, Maluf NK, Tripet B, Churchill ME, Tyler JK. 2005. ASF1 binds to a heterodimer of histones $\mathrm{H} 3$ and H4: A twostep mechanism for the assembly of the $\mathrm{H} 3-\mathrm{H} 4$ heterotetramer on DNA. Biochemistry 44: 13673-13682.

Erhardt S, Mellone BG, Betts CM, Zhang W, Karpen GH, Straight AF. 2008. Genome-wide analysis reveals a cell cycle-dependent mechanism controlling centromere propagation. J Cell Biol 183: $805-818$.

Fitzgerald-Hayes M, Clarke L, Carbon J. 1982. Nucleotide sequence comparisons and functional analysis of yeast centromere DNAs. Cell 29: 235-244.

Foltz DR, Jansen LET, Black BE, Bailey AO, Yates JR III, Cleveland DW. 2006. The human CENP-A centromeric nucleosomeassociated complex. Nat Cell Biol 8: 458-469.

Foltz DR, Jansen LE, Bailey AO, Yates JR III, Bassett EA, Wood S, Black BE, Cleveland DW. 2009. Centromere-specific assembly of CENP-A nucleosomes is mediated by HJURP. Cell 137: 472-484.

Fujita Y, Hayashi T, Kiyomitsu T, Toyoda Y, Kokubu A, Obuse C, Yanagida M. 2007. Priming of centromere for CENP-A recruit-

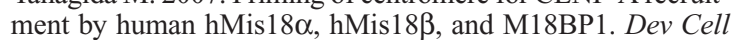
12: $17-30$.

Furuyama T, Henikoff S. 2009. Centromeric nucleosomes induce positive DNA supercoils. Cell 138: 104-113.

Groth A, Corpet A, Cook AJ, Roche D, Bartek J, Lukas J, Almouzni G. 2007a. Regulation of replication fork progression through histone supply and demand. Science 318: 1928-1931.

Groth A, Rocha W, Verreault A, Almouzni G. 2007b. Chromatin challenges during DNA replication and repair. Cell 128: 721733.

Han F, Lamb JC, Birchler JA. 2006. High frequency of centromere inactivation resulting in stable dicentric chromosomes of maize. Proc Natl Acad Sci 103: 3238-3243.

Hayashi T, Fujita Y, Iwasaki O, Adachi Y, Takahashi K, Yanagida M. 2004. Mis16 and Mis18 are required for CENP-A loading and histone deacetylation at centromeres. Cell 118: 715-729.

Hayes F, Barilla D. 2006. Assembling the bacterial segrosome. Trends Biochem Sci 31: 247-250.

Hemmerich P, Weidtkamp-Peters S, Hoischen C, Schmiedeberg L, Erliandri I, Diekmann S. 2008. Dynamics of inner kinetochore assembly and maintenance in living cells. J Cell Biol 180: 1101-1114.

Henikoff S, Ahmad K, Malik HS. 2001. The centromere paradox: 
Stable inheritance with rapidly evolving DNA. Science 293: 1098-1102.

Hori T, Amano M, Suzuki A, Backer CB, Welburn JP, Dong Y, McEwen BF, Shang WH, Suzuki E, Okawa K, et al. 2008a. CCAN makes multiple contacts with centromeric DNA to provide distinct pathways to the outer kinetochore. Cell 135: 1039 1052.

Hori T, Okada M, Maenaka K, Fukagawa T. 2008b. CENP-O class proteins form a stable complex and are required for proper kinetochore function. Mol Biol Cell 19: 843-854.

Howman EV, Fowler KJ, Newson AJ, Redward S, MacDonald AC, Kalitsis P, Choo KH. 2000. Early disruption of centromeric chromatin organization in centromere protein A (Cenpa) null mice. Proc Natl Acad Sci 97: 1148-1153.

Jackson V. 1990. In vivo studies on the dynamics of histone-DNA interaction: Evidence for nucleosome dissolution during replication and transcription and a low level of dissolution independent of both. Biochemistry 29: 719-731.

Jansen LE, Black BE, Foltz DR, Cleveland DW. 2007. Propagation of centromeric chromatin requires exit from mitosis. J Cell Biol 176: 795-805.

Jiang J, Birchler JA, Parrott WA, Dawe RK. 2003. A molecular view of plant centromeres. Trends Plant Sci 8: 570-575.

Kato T, Sato N, Hayama S, Yamabuki T, Ito T, Miyamoto M, Kondo S, Nakamura Y, Daigo Y. 2007. Activation of Holliday junction recognizing protein involved in the chromosomal stability and immortality of cancer cells. Cancer Res 67: 8544-8553.

Keppler A, Gendreizig S, Gronemeyer T, Pick H, Vogel H, Johnsson K. 2003. A general method for the covalent labeling of fusion proteins with small molecules in vivo. Nat Biotechnol 21: 86-89.

Keppler A, Pick H, Arrivoli C, Vogel H, Johnsson K. 2004. Labeling of fusion proteins with synthetic fluorophores in live cells. Proc Natl Acad Sci 101: 9955-9959.

Kingston IJ, Yung JS, Singleton MR. 2011. Biophysical characterisation of the centromere-specific nucleosome from budding yeast. J Biol Chem 286: 4021-4026.

Kline SL, Cheeseman IM, Hori T, Fukagawa T, Desai A. 2006. The human Mis 12 complex is required for kinetochore assembly and proper chromosome segregation. J Cell Biol 173: 9-17.

Klinov DV, Neretina TV, Prokhorov VV, Dobrynina TV, Aldarov KG, Demin VV. 2009. High-resolution atomic force microscopy of DNA. Biochemistry (Mosc) 74: 1150-1154.

Kornberg RD, Thomas JO. 1974. Chromatin structure; oligomers of the histones. Science 184: 865-868.

Lagana A, Dorn JF, De Rop V, Ladouceur AM, Maddox AS, Maddox PS. 2010. A small GTPase molecular switch regulates epigenetic centromere maintenance by stabilizing newly incorporated CENP-A. Nat Cell Biol 12: 1186-1193.

Lavelle C, Recouvreux P, Wong H, Bancaud A, Viovy JL, Prunell A, Victor JM. 2009. Right-handed nucleosome: Myth or reality? Cell 139: 1216-1217; author reply 1217-1218.

Lechner J, Carbon J. 1991. A 240 kd multisubunit protein complex, $\mathrm{CBF} 3$, is a major component of the budding yeast centromere. Cell 64: 717-725.

Luger K, Mader AW, Richmond RK, Sargent DF, Richmond TJ. 1997. Crystal structure of the nucleosome core particle at 2.8 Å resolution. Nature 389: 251-260.

Maddox PS, Hyndman F, Monen J, Oegema K, Desai A. 2007. Functional genomics identifies a Myb domain-containing protein family required for assembly of CENP-A chromatin. J Cell Biol 176: 757-763.

Manuelidis L, Wu JC. 1978. Homology between human and simian repeated DNA. Nature 276: 92-94.

Mellone BG, Allshire RC. 2003. Stretching it: Putting the CEN(PA) in centromere. Curr Opin Genet Dev 13: 191-198.

Mizuguchi G, Xiao H, Wisniewski J, Smith MM, Wu C. 2007. Nonhistone $\mathrm{Scm} 3$ and histones $\mathrm{CenH} 3-\mathrm{H} 4$ assemble the core of centromere-specific nucleosomes. Cell 129: 1153-1164.

Moggs JG, Grandi P, Quivy JP, Jonsson ZO, Hubscher U, Becker PB, Almouzni G. 2000. A CAF-1-PCNA-mediated chromatin assembly pathway triggered by sensing DNA damage. Mol Cell Biol 20: $1206-1218$.
Murphy WJ, Larkin DM, Everts-van der Wind A, Bourque G, Tesler G, Auvil L, Beever JE, Chowdhary BP, Galibert F, Gatzke L, et al. 2005. Dynamics of mammalian chromosome evolution inferred from multispecies comparative maps. Science 309: 613-617.

Natsume R, Eitoku M, Akai Y, Sano N, Horikoshi M, Senda T. 2007. Structure and function of the histone chaperone CIA/ASF1 complexed with histones H3 and H4. Nature 446: 338-341.

Obuse C, Yang H, Nozaki N, Goto S, Okazaki T, Yoda K. 2004. Proteomics analysis of the centromere complex from HeLa interphase cells: UV-damaged DNA binding protein 1 (DDB-1) is a component of the CEN-complex, while BMI-1 is transiently co-localized with the centromeric region in interphase. Genes Cells 9: 105-120.

Okada M, Cheeseman IM, Hori T, Okawa K, McLeod IX, Yates JR III, Desai A, Fukagawa T. 2006. The CENP-H-I complex is required for the efficient incorporation of newly synthesized CENP-A into centromeres. Nat Cell Biol 8: 446-457.

Okada M, Okawa K, Isobe T, Fukagawa T. 2009. CENP-H-containing complex facilitates centromere deposition of CENP-A in cooperation with FACT and CHD1. Mol Biol Cell 20: 3986-3995.

O'Keefe RT, Henderson SC, Spector DL. 1992. Dynamic organization of DNA replication in mammalian cell nuclei: Spatially and temporally defined replication of chromosome-specific $\alpha$ satellite DNA sequences. J Cell Biol 116: 1095-1110.

Orphanides G, LeRoy G, Chang CH, Luse DS, Reinberg D. 1998. FACT, a factor that facilitates transcript elongation through nucleosomes. Cell 92: 105-116.

Palmer DK, Margolis RL. 1985. Kinetochore components recognized by human autoantibodies are present on mononucleosomes. Mol Cell Biol 5: 173-186.

Perpelescu M, Nozaki N, Obuse C, Yang H, Yoda K. 2009. Active establishment of centromeric CENP-A chromatin by RSF complex. J Cell Biol 185: 397-407.

Pidoux AL, Choi ES, Abbott JK, Liu X, Kagansky A, Castillo AG, Hamilton GL, Richardson W, Rappsilber J, He X, et al. 2009. Fission yeast $\mathrm{Scm} 3$ : A CENP-A receptor required for integrity of subkinetochore chromatin. Mol Cell 33: 299-311.

Regnier V, Vagnarelli P, Fukagawa T, Zerjal T, Burns E, Trouche D, Earnshaw W, Brown W. 2005. CENP-A is required for accurate chromosome segregation and sustained kinetochore association of BubR1. Mol Cell Biol 25: 3967-3981.

Ribeiro SA, Vagnarelli P, Dong Y, Hori T, McEwen BF, Fukagawa T, Flors C, Earnshaw WC. 2010. A super-resolution map of the vertebrate kinetochore. Proc Natl Acad Sci 107: 10484-10489.

Santaguida S, Musacchio A. 2009. The life and miracles of kinetochores. EMBO J 28: 2511-2531.

Schuh M, Lehner CF, Heidmann S. 2007. Incorporation of Drosophila CID/CENP-A and CENP-C into centromeres during early embryonic anaphase. Curr Biol 17: 237-243.

Sekulic N, Bassett EA, Rogers DJ, Black BE. 2010. The structure of (CENP-A-H4) 2 reveals physical features that mark centromeres. Nature 467: 347-351.

Shelby RD, Vafa O, Sullivan KF. 1997. Assembly of CENP-A into centromeric chromatin requires a cooperative array of nucleosomal DNA contact sites. J Cell Biol 136: 501-513.

Shelby RD, Monier K, Sullivan KF. 2000. Chromatin assembly at kinetochores is uncoupled from DNA replication. J Cell Biol 151: $1113-1118$.

Shibahara K, Stillman B. 1999. Replication-dependent marking of DNA by PCNA facilitates CAF-1-coupled inheritance of chromatin. Cell 96: 575-585.

Shuaib M, Ouararhni K, Dimitrov S, Hamiche A. 2010. HJURP binds CENP-A via a highly conserved N-terminal domain and mediates its deposition at centromeres. Proc Natl Acad Sci 107: $1349-1354$.

Silva MC, Jansen LE. 2009. At the right place at the right time: Novel CENP-A binding proteins shed light on centromere assembly. Chromosoma 118: 567-574.

Smith S, Stillman B. 1989. Purification and characterization of CAF-I, a human cell factor required for chromatin assembly during DNA replication in vitro. Cell 58: 15-25. 
Smith S, Stillman B. 1991. Stepwise assembly of chromatin during DNA replication in vitro. EMBO J 10: 971-980.

Stoler S, Keith KC, Curnick KE, Fitzgerald-Hayes M. 1995. A mutation in CSE4, an essential gene encoding a novel chromatinassociated protein in yeast, causes chromosome nondisjunction and cell cycle arrest at mitosis. Genes Dev 9: 573-586.

Suda M, Iwai K. 1979. Identification of suberimidate cross-linking sites of four histone sequences in H1-depleted chromatin. Histone arrangement in nucleosome core. J Biochem 86: 16591670.

Sullivan BA, Karpen GH. 2004. Centromeric chromatin exhibits a histone modification pattern that is distinct from both euchromatin and heterochromatin. Nat Struct Mol Biol 11: 1076-1083.

Sullivan BA, Schwartz S. 1995. Identification of centromeric antigens in dicentric Robertsonian translocations: CENP-C and CENP-E are necessary components of functional centromeres. Hum Mol Genet 4: 2189-2197.

Sullivan KF, Hechenberger M, Masri K. 1994. Human CENP-A contains a histone $\mathrm{H} 3$ related histone fold domain that is required for targeting to the centromere. J Cell Biol 127: 581-592.

Surcel A, Koshland D, Ma H, Simpson RT. 2008. Cohesin interaction with centromeric minichromosomes shows a multi-complex rod-shaped structure. PLoS ONE 3: e2453. doi: 10.1371/ journal.pone. 0002453 .

Tagami H, Ray-Gallet D, Almouzni G, Nakatani Y. 2004. Histone H3.1 and H3.3 complexes mediate nucleosome assembly pathways dependent or independent of DNA synthesis. Cell 116: 51-61.

Takahashi K, Chen ES, Yanagida M. 2000. Requirement of Mis6 centromere connector for localizing a CENP-A-like protein in fission yeast. Science 288: 2215-2219.
Takahashi K, Takayama Y, Masuda F, Kobayashi Y, Saitoh S. 2005. Two distinct pathways responsible for the loading of CENP-A to centromeres in the fission yeast cell cycle. Philos Trans $R$ Soc Lond B Biol Sci 360: 595-607.

Ventura M, Archidiacono N, Rocchi M. 2001. Centromere emergence in evolution. Genome Res 11: 595-599.

Ventura M, Weigl S, Carbone L, Cardone MF, Misceo D, Teti M, D'Addabbo P, Wandall A, Bjorck E, de Jong PJ, et al. 2004. Recurrent sites for new centromere seeding. Genome Res 14: 1696-1703.

Warburton PE, Cooke CA, Bourassa S, Vafa O, Sullivan BA, Stetten G, Gimelli G, Warburton D, Tyler-Smith C, Sullivan KF, et al. 1997. Immunolocalization of CENP-A suggests a distinct nucleosome structure at the inner kinetochore plate of active centromeres. Curr Biol 7: 901-904.

Weintraub H, Worcel A, Alberts B. 1976. A model for chromatin based upon two symmetrically paired half-nucleosomes. Cell 9: 409-417.

Willard HF. 1985. Chromosome-specific organization of human alpha satellite DNA. Am J Hum Genet 37: 524-532.

Willard HF, Waye JS. 1987. Hierarchical order in chromosomespecific human alpha satellite DNA. Trends Genet 3: 192-198.

Williams JS, Hayashi T, Yanagida M, Russell P. 2009. Fission yeast $\mathrm{Scm} 3$ mediates stable assembly of Cnp1/CENP-A into centromeric chromatin. Mol Cell 33: 287-298.

Xu M, Long C, Chen X, Huang C, Chen S, Zhu B. 2010. Partitioning of histone $\mathrm{H} 3-\mathrm{H} 4$ tetramers during DNA replicationdependent chromatin assembly. Science 328: 94-98.

Zachariae W, Schwab M, Nasmyth K, Seufert W. 1998. Control of cyclin ubiquitination by CDK-regulated binding of Hct1 to the anaphase promoting complex. Science 282: 1721-1724. 


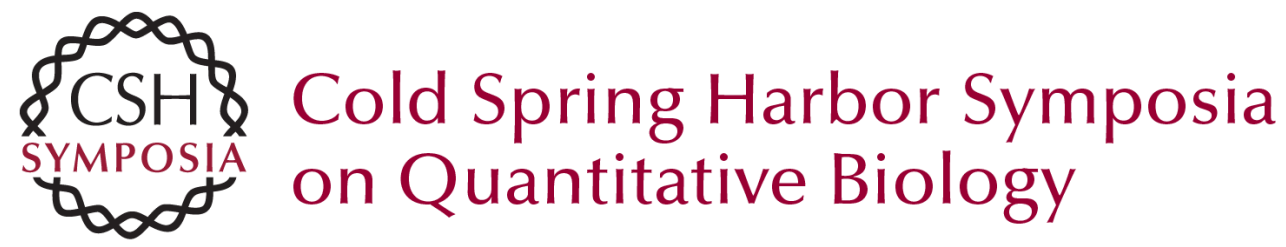

\section{Centromere Identity, Function, and Epigenetic Propagation across Cell Divisions}

B.E. Black, L.E.T. Jansen, D.R. Foltz, et al.

Cold Spring Harb Symp Quant Biol 2010 75: 403-418 originally published online April 5, 2011 Access the most recent version at doi:10.1101/sqb.2010.75.038

References This article cites 111 articles, 42 of which can be accessed free at: http://symposium.cshlp.org/content/75/403.full.html\#ref-list-1

License

Email Alerting Receive free email alerts when new articles cite this article - sign up in Service the box at the top right corner of the article or click here. 